\title{
Zircon texture and chemical composition as a guide to magmatic processes and mixing in a granitic environment and coeval volcanic system
}

\author{
Damien Gagnevin · J. Stephen Daly • \\ Andreas Kronz
}

Received: 21 October 2008/Accepted: 24 August 2009/Published online: 11 September 2009

(C) Springer-Verlag 2009

\begin{abstract}
This study documents the chemical and textural responses of zircon in the Elba igneous complex, with particular reference to the 7- to 7.8-Ma-old Monte Capanne pluton in relation to its coeval volcanic counterpart $(\mathrm{Ca}-$ praia), using BSE imaging and quantitative electron microprobe analyses. The Monte Capanne pluton displays multiple field and geochemical evidence for magma mixing. The samples we have investigated (including monzogranitic, mafic enclave and dyke samples) display similar zircon textures and are associated with an extremely large range of trace and minor element (Hf, Y, HREE, Th, U) compositions, which contrast with relatively simple textures and zoning patterns in zircons from a Capraia dacite. We have used a relatively simple textural classification (patchy zoning, homogenous cores, oscillatory zoning and unzoned zircon) as the basis for discussing the chemical composition and chemical variation within zircons from the Monte Capanne pluton. Based on these data and other works (Dini et al. 2004 in Lithos 78:101-118, 2004), it is inferred that mixing between metaluminous and peraluminous melts occurred early in the evolution of the Monte Capanne magma chamber. In particular, mixing was
\end{abstract}

Communicated by J. Hoefs.

Electronic supplementary material The online version of this article (doi:10.1007/s00410-009-0443-0) contains supplementary material, which is available to authorized users.

D. Gagnevin $(\bowtie) \cdot$ J. S. Daly

UCD School of Geological Sciences, University College Dublin,

Belfield, Dublin 4, Ireland

e-mail: Damien.Gagnevin@ucd.ie

A. Kronz

Geoscience Center Göttingen, Georg-August-Universität

Göttingen, Göttingen, Germany responsible for the development of the patchy-zoning texture in the zircon cores, which was associated with reactions between other accessory phases (including monazite, apatite, allanite), which we infer to have significantly affected the Th distribution in zircon. Zircons from the MC pluton displaying "homogeneous cores" have chemical affinities with zircons in the coeval Capraia volcanic system, consistent with the participation of a Capraia-like mantle end-member during mixing. Further zircon growth in the MC pluton produced the oscillatory zoning texture, which records both long-term (crystal fractionation) and transient (recharge with both silicic and mafic magmas) events in a hybrid magma chamber. It is inferred that $\mathrm{Hf}$ and the $\mathrm{Th} / \mathrm{U}$ ratio cannot be used alone to infer magmatic processes due to their dependency on temperature, nor are they a diagnostic feature of xenocrystic grains. This study shows that zircon chemistry coupled with detailed textural analysis can provide a powerful tool to elucidate the complex evolution of a magma system.

Keywords Granite petrology $\cdot$ Zircon - Elba · Capraia · Electron microprobe $\cdot$ Magma mixing

\section{Introduction}

In recent years, geochemical and isotopic studies of zircon have contributed significantly to our understanding of silicic magmatic phenomena, including features such as incremental assembly of magma batches, thermal rejuvenation, residence time and the extent of magmatic recycling (e.g. Lowenstern et al. 2000; Wang et al. 2002; Miller and Wooden 2004; Kemp et al. 2007; Lowery Claiborne et al. 2006; Yang et al. 2007; Miller et al. 2007). Zircon is an extremely robust mineral that can crystallize over a wide 
range of magmatic temperatures, essentially depending on the bulk composition of the host magma (and associated source rock; Watson and Harrison 1983; Harrison and Watson 1983). Sluggish diffusion for most elements in zircon (Cherniak and Watson 2003) makes it a suitable target for petrological investigations using the different geochemical tools presently available, although recent studies have shown that crystal-plastic deformation may affect the trace element distribution (e.g. Timms et al. 2006; Reddy et al. 2009). The chemical composition of zircon may be used to elaborate many magmatic processes, including crystal fractionation (Wark and Miller 1993; Thomas et al. 2002; Pettke et al. 2005; Lowery Claiborne et al. 2006), interaction with hydrothermal fluids (Thomas et al. 2002; Hoskin 2005) and/ or magma mixing (Wang et al. 2002; Belousova et al. 2006), as well as being a potential source indicator (Belousova et al. 2002). The zircon crystallization history may provide unique insights into magma petrogenesis, provided that the magma system is reasonably well characterised geochemically and isotopically. In such cases, coupled CL-BSE imaging and chemical analysis of zircon has the potential to record complex magma histories (Hanchar and Miller 1993; Wark and Miller 1993) that can be coupled to crystallization of other accessory minerals during melt differentiation (Hoskin et al. 2000; Dini et al. 2004). Spider diagrams are commonly used to report trace element variations within individual zircon, or for entire zircon populations. Detailed intra-grain zonation patterns, however, have only been reported in few studies (Hanchar and Miller 1993; Wark and Miller 1993; Poller et al. 2001; Lowery Claiborne et al. 2006), and in most cases only for very few zircon grains, or not at a level of precision necessary to infer magma processes in detail.

This paper focuses on the Monte Capanne (MC) pluton, a geochemically well-characterised intrusion, which has been the subject of intensive whole-rock and mineral-scale studies (Poli 1992; Dini et al. 2002; Gagnevin et al. 2004, $2005 a, b)$. Building on previous studies of textural, chemical and isotopic variations within K-feldspar megacrysts (Gagnevin et al. 2005a, b), we want to test whether or not zircon is another useful tracer for magma processes and mixing in the MC pluton, as suggested in other intrusions (Wang et al. 2002; Lowery Claiborne et al. 2006). The textural and chemical responses of zircon during growth in a continuously changing magmatic environment will be addressed in the light of backscattered electron (BSE) imaging and quantitative analyses by electron microprobe in the different magma products that constitute the MC intrusion (mafic enclaves, mafic dykes, granite porphyry) and in a sample from a coeval volcanic rock (Capraia). Extensive in situ ion microprobe $\mathrm{U}-\mathrm{Pb}$ dating on zircon from the Tuscan magmatic province (including Elba and Capraia) will be published elsewhere. Here, we focus on a detailed account of zircon texture and chemistry, and we show that zircon provides an independent and robust record of magma mixing that may provide insight into the nature of the components involved in mixing.

\section{Geological background and petrological inferences}

The Monte Capanne pluton (Fig. 1) is a young granitic intrusion (7.0-7.8 Ma; Daly et al. 2007). It occupies the western part of the Elba igneous complex (Italy), which also comprises granite porphyries (Central and Western Elba; 8-7.4 Ma; Dini et al. 2002), and the Porto Azzurro pluton (Eastern Elba; 5.1 Ma; Conticelli et al. 2001). The Elba igneous complex was emplaced during regional extension, during the opening of the Tyrrhenian Sea (late Miocene) associated with subduction, roll-back and retreat of the subducting Adriatic lithosphere (e.g. Cavinato and De Celles 1999). It originally formed a stacked intrusion ('Christmastree laccolith'; Rocchi et al. 2002) that was unroofed by lowangle gravity sliding (Westerman et al. 2004).

Relative to other plutons in the Tuscan Archipelago (e.g. the 5-Ma-old Giglio and 7-Ma-old Montecristo plutons), the MC pluton has received particular attention due to abundant and fresh exposures. We refer to Dini et al. $(2002,2004)$ and Gagnevin et al. (2004, 2005a) for details on the petrology of the MC pluton. Briefly, the pluton has a bulk monzogranitic composition, with the mineralogy chiefly consisting of plagioclase, microperthitic K-feldspar, quartz and biotite, with apatite, zircon, allanite and monazite as accessory minerals. Based on field, textural and chemical data, the intrusion is divided into the Sant' Andrea and Pomonte facies (Dini et al. 2002; Gagnevin et al. 2008a), although their Sr and Nd isotopic compositions are almost indistinguishable (initial ${ }^{87} \mathrm{Sr} /{ }^{86} \mathrm{Sr} \sim 0.715$ and ${ }^{143} \mathrm{Nd} /{ }^{144} \mathrm{Nd} \sim 0.5122$ ) (Gagnevin et al. 2004). Similarly, mafic microgranular enclaves (MME; Poli 1992), zoned K-feldspar megacrysts (Gagnevin et al. 2005a, b) and reaction micro-textures between accessory minerals (Dini et al. 2004) occur widely throughout the intrusion, all of which have been interpreted as evidence for mixing between mantle and crustal magmas. The pluton is cut by a series of late mafic, 'Orano' dykes (Poli 1992), which have a similar bulk chemical composition (granodioritic to monzogranitic) to the MMEs. Felsic (aplitic, leucogranitic and pegmatitic) dykes are abundant and widespread throughout the pluton. Granite porphyries also occur at its periphery (Fig. 1) and have similar geochemical characteristics to the MC monzogranite.

The Capraia volcano, which is situated north of Elba, constitutes the only volcanic edifice within the Tuscan Archipelago. It was active mainly between 7 and $8 \mathrm{Ma}$ (Gagnevin et al. 2008b), that is, essentially coeval with the emplacement of the Monte Capanne pluton. Volcanic products range in composition from andesite to dacite and 


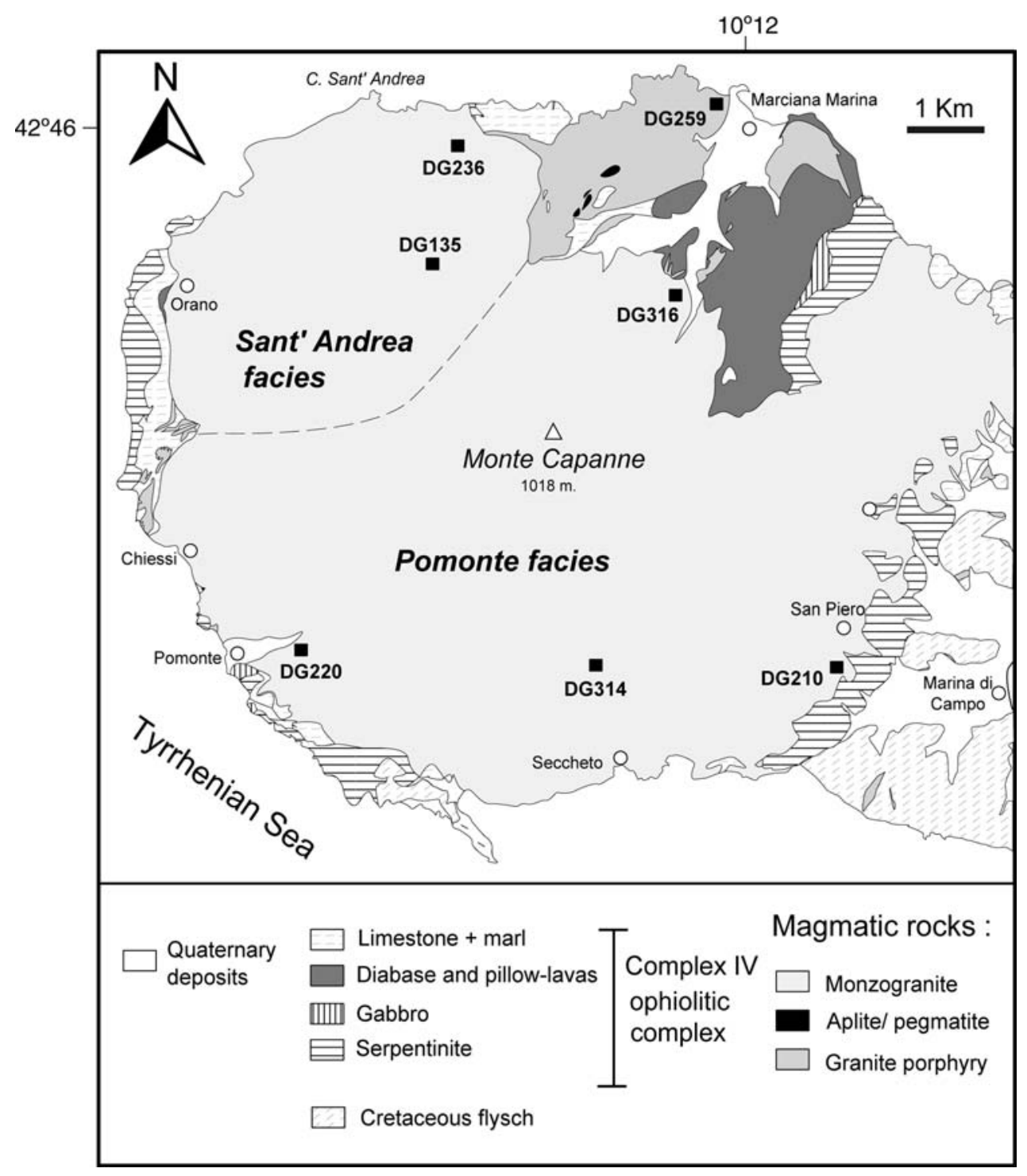

Fig. 1 Geological map of the western part of Elba Island (after Trevisan and Marinelli 1967) showing the Monte Capanne pluton and the surrounding geology. Open circles place names, filled squares sample localities with sample numbers, long-dashed lines

rhyolite, with a predominantly high-K calc-alkaline signature. The large range of chemical and isotopic composition of the lavas both at the whole-rock (Poli and Perugini 2003) and mineral (Gagnevin et al. 2007) scales is indicative of open-system behaviour. Importantly, a Capraialike, mantle-derived end-member has been inferred to have been involved in mixing with peraluminous melts in the Elba igneous complex (Poli 1992; Gagnevin et al. 2004).

\section{Samples}

Zircon is a ubiquitous mineral throughout the Elba igneous complex. We have investigated three samples (Fig. 1) subdivisions of the pluton into Sant' Andrea (Dini et al. 2002) and Pomonte facies (Gagnevin et al., 2008a; previously subdivided into the San Piero and San Francesco facies; Dini et al. 2002)

of MC pluton monzogranite (DG236, DG314 and DG316), two MMEs (DG210 and DG220), one Orano dyke (DG135), and one granite porphyry (DG259). Additionally, one dacitic sample from Capraia (DG05-01) has been studied. Most of these samples (Table 1) are well characterised petrographically, chemically (major and trace elements) and isotopically ( $\mathrm{Sr}$ and $\mathrm{Nd}$ ) (Gagnevin et al. 2004). Samples DG236 and DG05-01 are petrographically similar to other rocks from the "Sant' Andrea facies" (Dini et al. 2002; Gagnevin et al. 2008a) in the MC pluton and dacite in Capraia Volcano, respectively, and are assumed to be geochemically similar to other rocks occurring in these areas (Bussy 1990; Gagnevin et al. 2004, 2007). 
Table 1 Whole-rock composition of rocks from the Monte Capanne pluton investigated in this study

\begin{tabular}{|c|c|c|c|c|c|c|}
\hline $\begin{array}{l}\text { Sample no. type } \\
\text { facies location }\end{array}$ & $\begin{array}{l}\text { DG210 MME } \\
\text { Pomonte San } \\
\text { Piero }\end{array}$ & $\begin{array}{l}\text { DG220 MME } \\
\text { Pomonte } \\
\text { Pomonte }\end{array}$ & $\begin{array}{l}\text { DG314 monzog. } \\
\text { Pomonte Seccheto }\end{array}$ & $\begin{array}{l}\text { DG316 monzog. } \\
\text { Pomonte Poggio }\end{array}$ & $\begin{array}{l}\text { DG135 Orano dyke } \\
\text { Sant'Andrea U. Masso }\end{array}$ & $\begin{array}{l}\text { DG259 } \\
\text { G. porphyry- } \\
\text { M. Mariana }\end{array}$ \\
\hline \multicolumn{7}{|c|}{ Major oxides (wt\%) } \\
\hline $\mathrm{SiO}_{2}$ & 63.83 & 65.31 & 68.45 & 68.99 & 63.83 & 71.61 \\
\hline $\mathrm{TiO}_{2}$ & 0.79 & 0.60 & 0.48 & 0.50 & 0.63 & 0.22 \\
\hline $\mathrm{Al}_{2} \mathrm{O}_{3}$ & 16.79 & 15.33 & 15.61 & 15.22 & 15.68 & 14.69 \\
\hline $\mathrm{Fe}_{2} \mathrm{O}_{3}$ & 2.37 & 1.86 & 1.23 & 1.33 & 1.95 & 0.76 \\
\hline $\mathrm{FeO}$ & 2.42 & 2.55 & 1.61 & 1.73 & 2.33 & 0.89 \\
\hline $\mathrm{MnO}$ & 0.10 & 0.10 & 0.08 & 0.06 & 0.09 & 0.05 \\
\hline $\mathrm{MgO}$ & 2.32 & 3.09 & 1.32 & 1.34 & 3.65 & 0.66 \\
\hline $\mathrm{CaO}$ & 4.51 & 3.61 & 2.34 & 1.95 & 3.12 & 1.58 \\
\hline $\mathrm{Na}_{2} \mathrm{O}$ & 3.58 & 3.50 & 3.21 & 3.05 & 3.26 & 3.32 \\
\hline $\mathrm{K}_{2} \mathrm{O}$ & 2.21 & 3.09 & 4.77 & 4.78 & 3.70 & 4.71 \\
\hline $\mathrm{P}_{2} \mathrm{O}_{5}$ & 0.19 & 0.17 & 0.14 & 0.15 & 0.16 & 0.07 \\
\hline LOI & 0.91 & 0.80 & 0.78 & 0.90 & 1.60 & 1.45 \\
\hline ASI & 1.38 & 1.26 & 1.26 & 1.29 & 1.31 & 1.23 \\
\hline Total & 100.02 & 100.01 & 100.02 & 100.00 & 100.00 & 100.01 \\
\hline \multicolumn{7}{|c|}{ Trace elements (ppm) } \\
\hline $\mathrm{Cr}$ & 56 & 177 & 50 & 68 & 171 & 16 \\
\hline $\mathrm{Rb}$ & 268 & 291 & 311 & 247 & 257 & 292 \\
\hline $\mathrm{Sr}$ & 210 & 224 & 193 & 151 & 218 & 159 \\
\hline $\mathrm{Zr}$ & 177 & 145 & 133 & 171 & 163 & 115 \\
\hline $\mathrm{Ba}$ & 179 & 233 & 354 & 436 & 363 & 257 \\
\hline \multicolumn{7}{|c|}{ Isotopic composition $^{\mathrm{a}}$} \\
\hline${ }^{87} \mathrm{Sr} /{ }^{86} \mathrm{Sr}_{\mathrm{i}}$ & 0.71468 & 0.71375 & 0.71488 & 0.71723 & 0.71362 & 0.71348 \\
\hline${ }^{143} \mathrm{Nd} /{ }^{144} \mathrm{Nd}_{\mathrm{i}}$ & 0.51213 & 0.51223 & 0.51219 & 0.51210 & 0.51221 & 0.51220 \\
\hline
\end{tabular}

Major elements are normalised to $100 \%$

MME mafic microgranular enclave, monzog. monzogranite, ASI aluminium saturation index

${ }^{\text {a }}$ Initial ratios calculated at $7 \mathrm{Ma}$

\section{Analytical methods}

Zircon was separated from $<250 \mu \mathrm{m}$ sieved fractions using standard heavy liquid techniques, handpicked and mounted in epoxy resin. Imaging and chemical analyses were performed using a JEOL 8900 RL electron microprobe at the Department of Geochemistry, 'Geowissenschafliches Zentrum der Universität Göttingen' (GZG). Prior to quantitative analysis, the grains were imaged using a panchromatic cathodoluminescence (CL) detector and high-energy backscattered electrons were recorded using a paired semiconductor detector, operating in compositional mode to obtain atomic number contrast (BSE). Generally, single scans were used, in order to minimise damage to the epoxy resin.

Most zircon analyses were carried out using a focused beam and 80-nA beam current. Most of zircon-forming major (Si, Zr) and minor (U, Th, HREE, Y, Hf, P) elements were analysed, together with trace element such as $\mathrm{Al}, \mathrm{Ca}$ and $\mathrm{Fe}$ in order to check the possible contribution of inclusions in zircon analyses. In all cases, these elements contribute to less than $0.1 \%$ to the zircon analyses. Analysis of $\mathrm{Ti}$ was attempted (20 ppm detection limit), but the resulting errors were too large due to the low Ti content of the MC zircons (20-50 ppm). This resulted in unacceptable errors for temperature estimations (Watson et al. 2006). Counting times on peak for the minor and major oxides were set as follows: $15 \mathrm{~s}$ for $\mathrm{SiO}_{2} ; 30 \mathrm{~s}$ for $\mathrm{ZrO}_{2}, \mathrm{FeO}$, $\mathrm{Dy}_{2} \mathrm{O}_{3}, \mathrm{Al}_{2} \mathrm{O}_{3}$ and $\mathrm{Er}_{2} \mathrm{O}_{3} ; 60$ s for $\mathrm{P}_{2} \mathrm{O}_{5}, \mathrm{HfO}_{2}, \mathrm{CaO}, \mathrm{Ho}_{2} \mathrm{O}_{3}$ and $\mathrm{Yb}_{2} \mathrm{O}_{3} ; 150 \mathrm{~s}$ for $\mathrm{UO}_{2}, \mathrm{ThO}_{2}$ and $\mathrm{Y}_{2} \mathrm{O}_{3}$. Under these conditions, the detection limits (calculated from counting statistics of the background signal, given at 2-sigma values) are $420 \mathrm{ppm}$ for $\mathrm{Zr}, 140 \mathrm{ppm}$ for $\mathrm{P}, 75 \mathrm{ppm}$ for $\mathrm{U}, 140 \mathrm{ppm}$ for Y, $130 \mathrm{ppm}$ for Hf, $80 \mathrm{ppm}$ for Th and $200 \mathrm{ppm}$ for $\mathrm{Yb}$. Analytical errors (1 sigma) were estimated from counting statistics for each analysis. The USNM Zircon standard (USNM 117288-3) and a synthetic zircon standard provided by courtesy of J. Hanchar (Hanchar et al. 2001) were repeatedly analysed every $40-50$ analyses. 

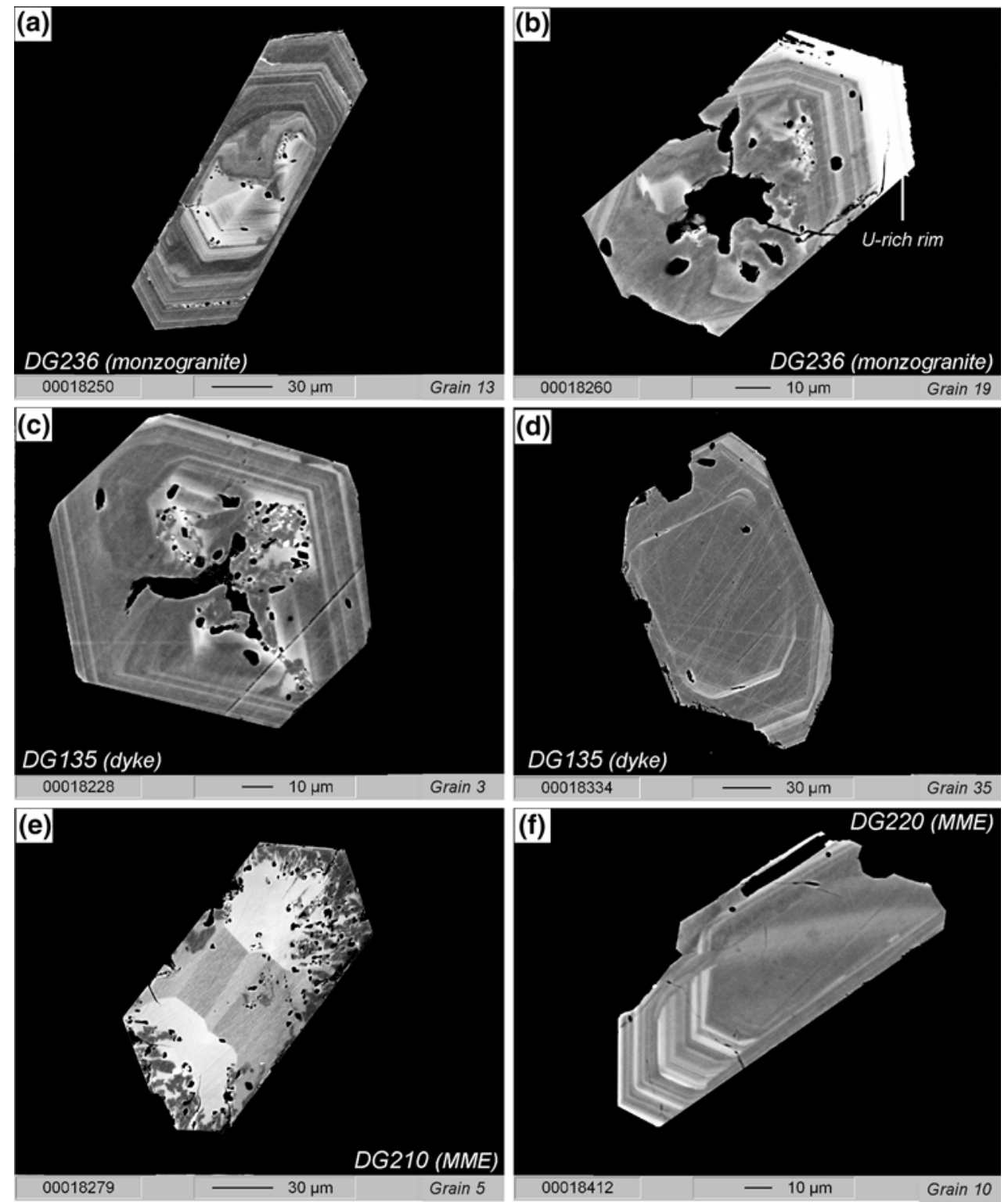

Fig. 2 Backscattered electron images showing the range of textures observed in zircons from the Monte Capanne monzogranite, mafic microgranular enclaves, Orano dyke and granite porphyry, and the dacite from Capraia. See text for details. a Grain 13, DG236, monzogranite: a weakly resorbed U-Th-Y-rich core is followed by oscillatory zoning interrupted by several resorption surfaces. b Grain 19, DG236, monzogranite: a strongly resorbed core, with a large pore near its centre, is followed by oscillatory zoning, with high U content at the rim ( $>60,000 \mathrm{ppm})$. c Grain 3, DG135, Orano dyke: similar highly resorbed cores to grain 19 , DG236, illustrating the widespread occurrence of this texture. d Grain 35, DG135, Orano dyke displaying a "homogenous, low U-Th-Y, core". The well-developed (100) crystal face in the core is typical of zircons in the Capraia dacite. e Grain 5, DG210, MME: irregular replacement of high U-Th-Y zircon by low $\mathrm{U}-\mathrm{Th}-\mathrm{Y}$ zircon along the edge of the grain, associated

\section{Zircon textures}

Zircon grains in the MC pluton display a great variety of textures (Fig. 2) visible in both CL and BSE images. High

with the development of small pores at the boundary between the two. f Grain 10, DG220, MME: homogenous, low U-Th-Y core made up of two growth stages separated by a resorption surface, succeeded by well-developed oscillatory zoning. g Grain 12, DG220, MME: inherited anhedral low U-Th-Y core, with a ${ }^{207} \mathrm{~Pb} /{ }^{206} \mathrm{~Pb}$ age of $2,509 \pm 14 \mathrm{Ma}$ (Daly and Gagnevin, unpublished data), overgrown by oscillatory zoning. h Grain 23, DG316, monzogranite: typical premagmatic xenocrystic zircon grain lacking a magmatic overgrowth. $\mathbf{i}$ and $\mathbf{j}$ Grains 63 and 23, DG259, granite porphyry: typical textures consisting in extensive oscillatory zoning, occasionally punctuated by resorption zones (j), and often terminated by high $\mathrm{U}-\mathrm{Th}-\mathrm{Y}$ zircon at the rim (i). $\mathbf{k}$ and $\mathbf{l}$ Grains 1, 14, 15, DG05-1, Capraia dacite: unlike zircons in the MC monzogranite and granite porphyry, zircons in the Capraia dacite do not exhibit strong BSE (hence compositional) variations. All three have prominent (100) prisms

BSE signals largely correspond to high atomic number elements, which, in this case, are mainly accounted for by $\mathrm{U}$ and, to a lesser extent, Th. However, radiation damage can also influence the BSE signal (Nasdala et al. 2006), 

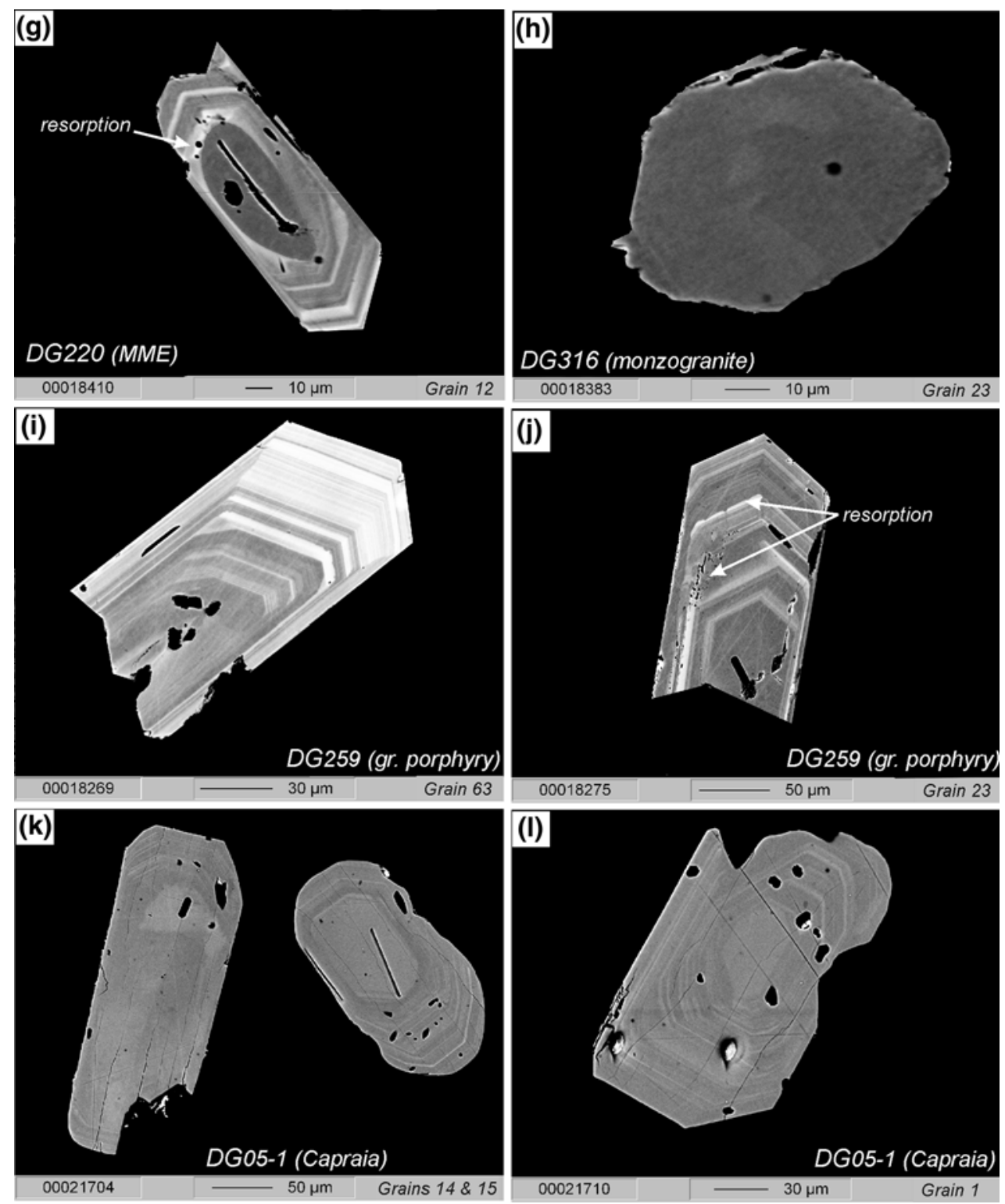

Fig. 2 continued

although the relatively young age of the magmatic zircons investigated in this study largely precludes this possibility (Murakami et al. 1991). When describing the zircon images, high and low BSE intensity domains are referred to as 'U-Th-Y-rich' and 'U-Th-Y-poor', respectively (Fig. 2). The CL signal is dominated by the incorporation of trace element, such as $\mathrm{Dy}^{3+}$ (Hanchar and Miller 1993), or alternatively, is due to lattice vacancies (Wiedenbeck et al. 2004). Generally, CL images are more diffuse than the BSE images, and are in most cases not directly related to the minor elements (Th, U, Hf, Y) of greatest interest. For these reasons, this study is largely based on the BSE images (Fig. 2), though CL images are also used. All the BSE and CL images obtained in this study are available in the Electronic Appendix 1.
Before going into the details of the zircon textures that we have encountered, general observations on zircon size and morphology can be made. Generally, grain size does not differ substantially according to the petrographic type (monzogranite, mafic enclave, Orano dyke) varying mainly between 90 and $260 \mu \mathrm{m}$. Zircon aspect ratios range from stubby (1:1 aspect ratio) to elongated (5:1), and are predominantly between 2:1 (e.g. Fig. 2b, d) and 3:1 (e.g. Fig. 2a, g). Importantly, the zircon textures described below occur independently of size and aspect ratio. The (110) prism and the (211) pyramidal faces are well developed in most zircons from the MC pluton. Zircons in the granite porphyry sample (Fig. 2i, j) and the Capraia dacite (Fig. 2k, 1) tend to be slightly larger (150-300 and $180-450 \mu \mathrm{m}$, respectively), than zircons in the MC monzogranite (and 


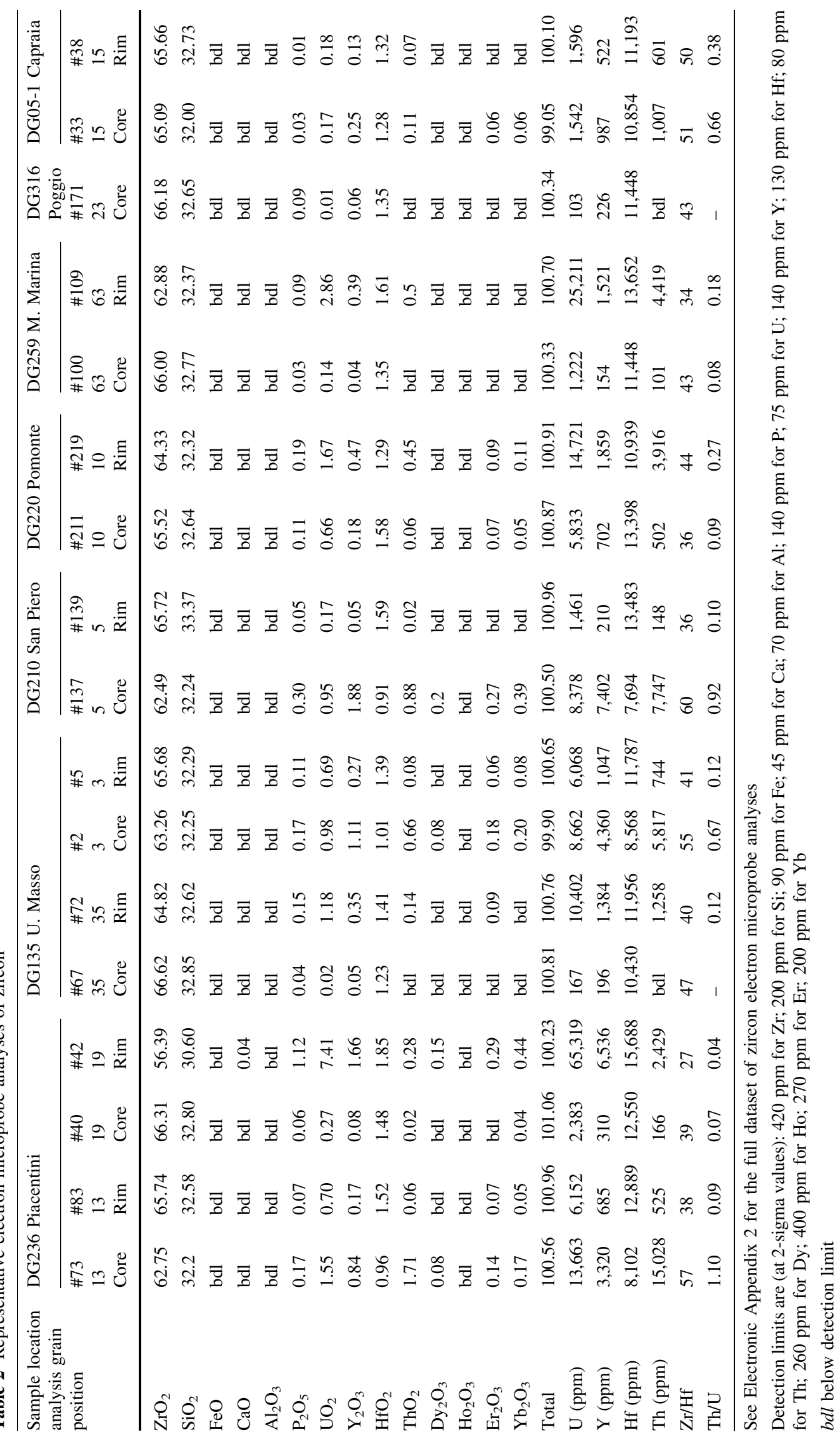


related products), with no distinctive differences in their aspect ratios. The Capraia zircons have prominent (100) prisms, with less developed (211) crystals faces (Fig. 2k, 1).

Monte Capanne pluton

\section{Patchy zoning}

Patchy zoning is the most common textural type in zircon cores, consists of U-Th-Y-poor zircon replacing U-Th-Yrich zircon (Fig. 2a, c). The extent of replacement is highly variable (even at the scale of a single thin-section), and proceeds up to almost complete obliteration of the U-Th-Yrich core (Fig. 2b). As seen in enclave sample DG210, replacement of U-Th-Y-rich zircon by U-Th-Y-poor zircon proceeds inwards (Fig. 2e) and is systematically accompanied by pores (or cavities), whose abundance and/or shape seems to correlate with the extent of resorption (Fig. 2a-d). High BSE, U-Th-rich micro-inclusions (possibly thorite) occasionally occur (Fig. 2c, f), but are not a systematic feature.

\section{Oscillatory zoning}

Oscillatory zoning in the MC zircons either consists of very narrow cyclic variations (1-3 $\mu$ m layers), or larger oscillatory zones (10-20 $\mu \mathrm{m}$; hereafter referred as 'growth bands'). Apart from enclave DG210, both types are found in all samples (Fig. 2). Growth bands alternate with narrow layers in most cases, and are thus regarded as being related to each other. Truncation sometimes occurs (Fig. 2a), indicating resorption. Overall, there is no clear pattern in oscillatory zoning that can be correlated from sample to sample, or even within individual samples. Oscillatory zoning is particularly well developed in zircons from granite porphyry DG259 (Fig. 2i, j), where resorption surfaces are also common (Fig. 2j).

\section{Homogenous cores}

Although less common, homogeneous zircon cores occur in almost all magma products (e.g. Fig. 2d). These have euhedral to subhedral shapes and are followed rimwards by oscillatory zoning. One low BSE homogenous core in DG220 is noteworthy for its strong anhedral habit (Fig. 2g). Euhedral cores are also common in the porphyry sample (Fig. 2i), and are sometimes followed by resorption (Fig. 2j).

\section{Unzoned to weakly zoned}

Unzoned to weakly zoned zircons are U-Th-Y poor and lack magmatic overgrowths. They have sub-rounded, anhedral outlines (e.g. Fig. 2h) and are especially abundant in monzogranite DG316, and are also present in the mafic enclaves, DG210 and DG220. These rounded morphologies are typical of inherited grains (Corfu et al. 2003), and they have been verified as such by in situ U-Pb SIMS analyses (Daly et al. 2007, Gagnevin et al. 2008b).

\section{Capraia (DG05-1)}

Zircons from the Capraia dacite display relatively simple textures without sharp BSE contrasts compared with those from the MC pluton. Most grains have homogenous, euhedral to subhedral cores, followed by fine-scale oscillatory zoning towards the rims (Fig. $2 \mathrm{k}, \mathrm{l}$ ). The contrast between the Capraia and MC pluton zircons suggests a simpler petrogenetic history for the former.

\section{Zircon chemistry}

Table 2 reports selected zircon analyses obtained by electron microprobe. The entire dataset is available in the Electronic Appendix 2.

Inter-grain compositional variations

The variety of textures observed in the MC zircons is associated with large chemical variations ranging up to rather high concentrations, e.g. in $\mathrm{Hf}(7,200-21,300 \mathrm{ppm})$, $\mathrm{Y}(<140-8,700 \mathrm{ppm}), \mathrm{U}(<75-65,300)$ and Th $(<80$ $46,200)$. Using the textural classification outlined above, covariation of $\mathrm{Hf}, \mathrm{Y}, \mathrm{U}$ and $\mathrm{Th}$ in the different zircon textural varieties of the MC pluton is illustrated using binary logarithmic diagrams (Fig. 3; Electronic Appendix 3). In Fig. 4, the MC zircon data are compared with the granite porphyry and Capraia zircon data (Electronic Appendix 3), which are not distinguished texturally, since they exhibit simpler textures, largely dominated by oscillatory zoning. Several points arise from these diagrams:

- The patchy-zoning texture in zircon displays a bimodal chemical distribution, that is, the BSE-brighter zircon has high $\mathrm{U}, \mathrm{Th}, \mathrm{Y}$ (and HREE) contents (Th/U $=0.28$ 1.45), but low Hf, and vice versa for the BSE-darker zircon $(\mathrm{Th} / \mathrm{U}=0-0.23) \quad$ (Fig. 3), with few or no intermediate compositions.

- This simple pattern contrasts with the considerable chemical scatter displayed by the oscillatory-zoned texture $(\mathrm{Th} / \mathrm{U}=0-0.83) \quad$ (Fig. 3). Excluding the Capraia dacite and granite porphyry zircons, about $50 \%$ of the data plot in the compositional gap between the patchy-zoning end-members (Fig. 3a, b, d), a feature largely inherited from the narrow type of oscillatory zoning (not shown). 


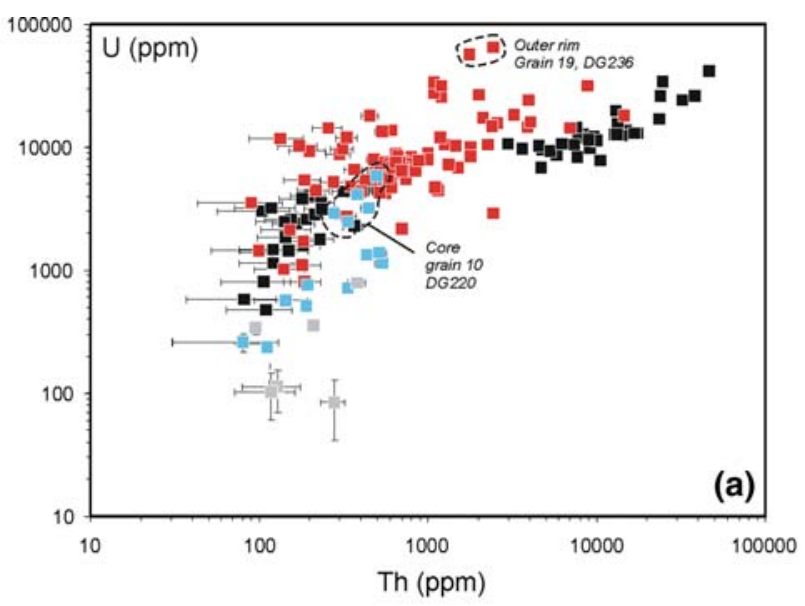

Patchy-zoning

Oscillatory-zoning

Homogenous core

Unzoned zircon/ inherited core
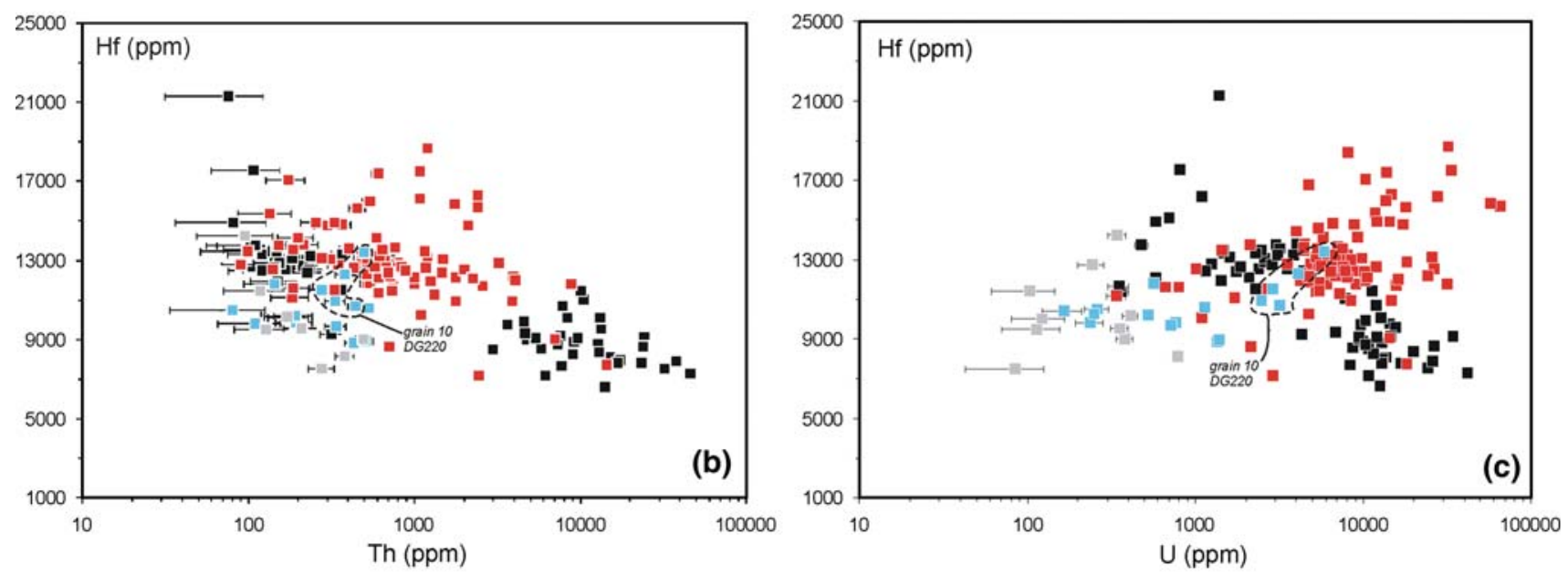

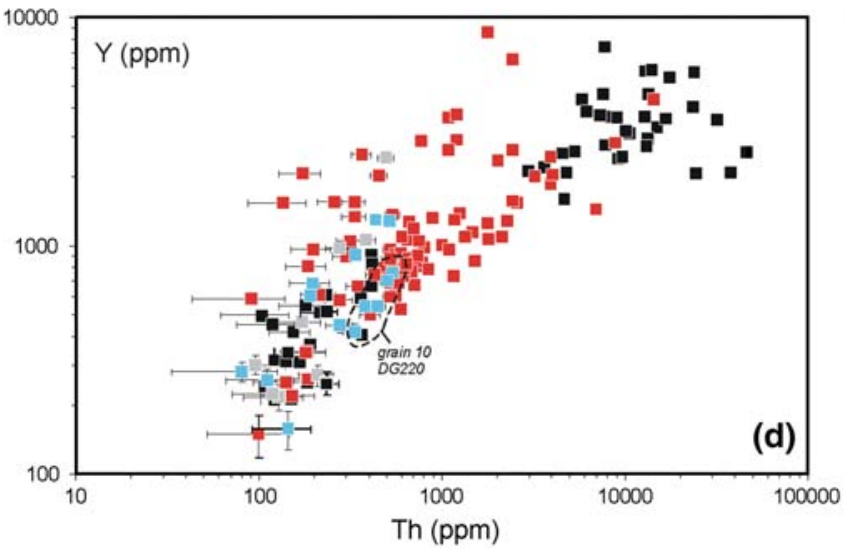

Fig. 3 Covariation of $\mathrm{Hf}, \mathrm{Y}, \mathrm{U}$ and Th in the different zircon textural varieties in the Monte Capanne pluton plotted in binary logarithmic diagrams. Reported errors are 1 sigma. Patchy-zoned zircons tend to

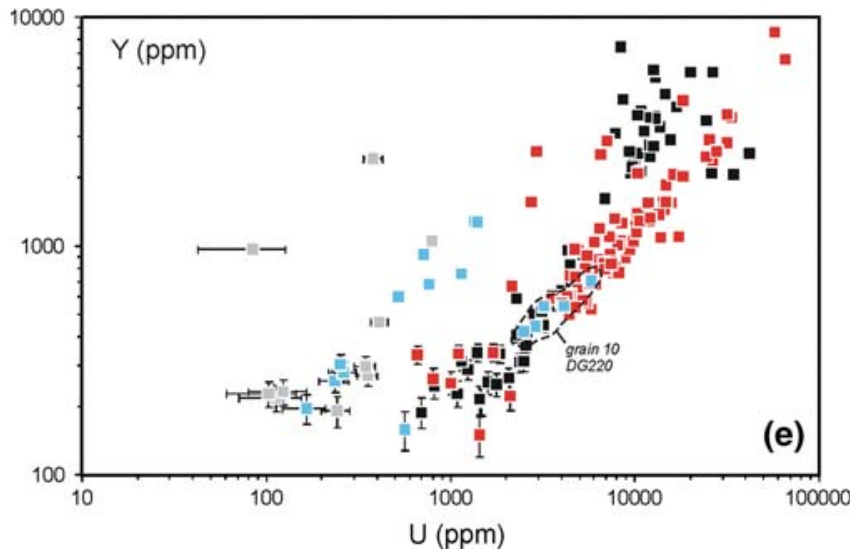

plot in two separate groups, bridged by the oscillatory variety, which also trend toward higher $\mathrm{U}$ and $\mathrm{Hf}$ contents. Homogenous cores and unzoned zircon exhibit distinct trends/fields. See text for details

content $(2,500-4,900 \mathrm{ppm})$ and lower $\mathrm{Th} / \mathrm{U}(0.09$ 0.14). In general, homogenous cores define separate fields in most diagrams (Fig. 3).

- Unzoned zircons (Th/U =0.28-3.28), inferred (or known from $\mathrm{U}-\mathrm{Pb}$ geochronology) to have a nonmagmatic, xenocrystic origin, have the most depleted 

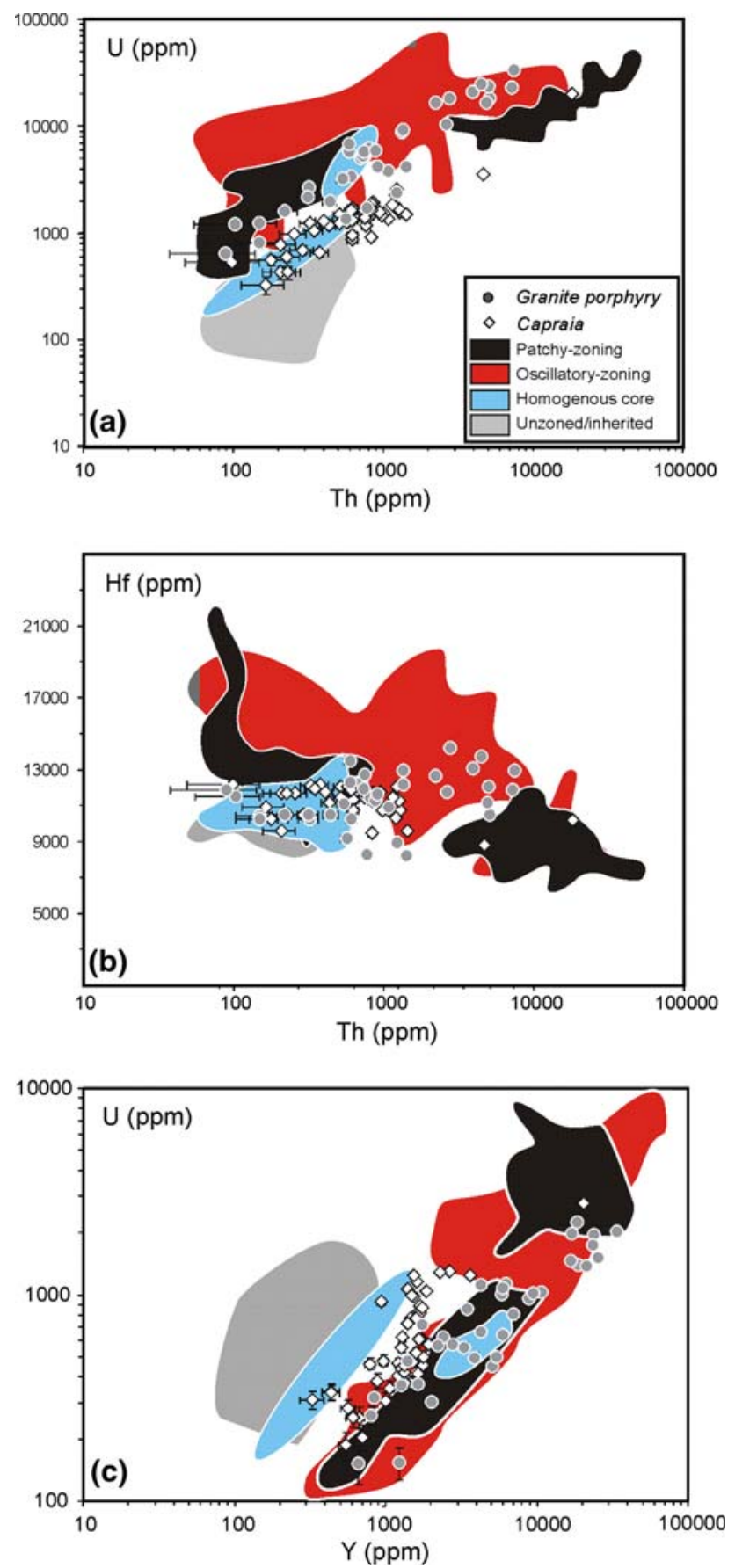

Fig. 4 Covariation of Hf, Y, U and Th in the different zircon textural varieties from the granite porphyry and Capraia compared with the fields for the MC pluton as defined in Fig. 4. Reported errors are 1 sigma. Note the chemical resemblance between the Capraia zircons and the homogenous cores (see $\mathbf{a}$ and $\mathbf{b}$ ). Zircons in the granite porphyry span a wider range of chemical composition, and have affinities with the oscillatory zoning texture (see $\mathbf{a}$ and $\mathbf{c}$ )

chemical signature $(\mathrm{U}<1,400 \mathrm{ppm}, \mathrm{Th}<400 \mathrm{ppm}$, $\mathrm{Y}<1,000 \mathrm{ppm}$ ) of all zircons investigated in this study, except for Hf (7,500-14,200 ppm) (Fig. 3).
Fig. 5 Selected $\mathrm{Y}, \mathrm{Th}, \mathrm{U}, \mathrm{Hf}$ and $\mathrm{Th} / \mathrm{U}$ compositional profiles in zircons from the Monte Capanne pluton and related products (mafic enclaves and Orano dyke). Electron microprobe spots, corresponding to the compositional profiles, are shown as white filled circles. Errors are smaller than symbol size

Their compositional field partly overlaps that of the homogenous cores.

- Zircons in the granite porphyry $(\mathrm{Th} / \mathrm{U}=0-0.50)$ exhibit a wide range of chemical composition (Fig. 4; U, 660-33,800; Th, 0-7,400; Y, 90-2,300 ppm) similar to the MC zircons, but define more consistent chemical trends than zircons in the MC monzogranite and related rocks.

- Zircons from Capraia are chemically similar to the MC zircons, especially the homogenous cores (Fig. 4).

Intra-grain compositional variations

In this section, we describe intra-grain textural and chemical features of zircon in the MC monzogranite, MMEs and dyke (Fig. 5), in the Capraia dacite and in the granite porphyry (Fig. 6).

In most cases, the high BSE zircon domains in the patchy-zoned cores have high Th, U, P, and Y (HREE) contents, but low Hf contents (7,500-10,000 ppm), and vice versa for low BSE zircon. Grain 13, DG236 (Fig. 5a) has a moderately resorbed core with elevated U-Th-Y, overgrown by an oscillatory-zoned rim. The boundary between the two coincides with a sharp decrease (especially in $\mathrm{Th}$ ) followed by a monotonic rimwards decrease in $\mathrm{U}$ and $\mathrm{Y}$. Such a clear transition is not as well displayed in zircons having homogenous cores (Fig. 5c), which instead display rather continuous core-to-rim chemical patterns. Grain 5 in mafic enclave DG210 (Fig. 5d) has the highest $\mathrm{Th}, \mathrm{Y}$ and $\mathrm{Th} / \mathrm{U}$ values of all zircons analysed in this study. In this sample, U-Th-Y-poor zircon replacing U-Th-Y-rich zircon (Fig. 2e) is characterised by a high Hf content (up to $21,300 \mathrm{ppm}$ ).

The extent of chemical variation in oscillatory-zoned zircon domains is highly variable (Fig. 5). However, zircons exhibiting a gradual increase in Th, U, P and $\mathrm{Y}$ towards the rim occur in all samples and seem to be the most common variety, irrespective of the nature of the grain's core (e.g. compare Fig. 5c with Fig. 5b). No consistency is observed in the outer rim composition. The bright rim in grain 19, DG236 (Figs. 2b; 3a; Table 2) has the highest $\mathrm{U}(65,300 \mathrm{ppm}), \mathrm{Y}(6,500 \mathrm{ppm})$ and $\mathrm{P}$ $(2,400 \mathrm{ppm})$ contents of all zircons.

A gradual rimwards enrichment in $\mathrm{Hf}, \mathrm{U}, \mathrm{Y}$ and Th is common in the granite porphyry zircons (Fig. 6a, b), which is reminiscent of some zircons in the MC monzogranite (e.g. Fig. 5e). U-Th-Y-rich rims are an almost ubiquitous 

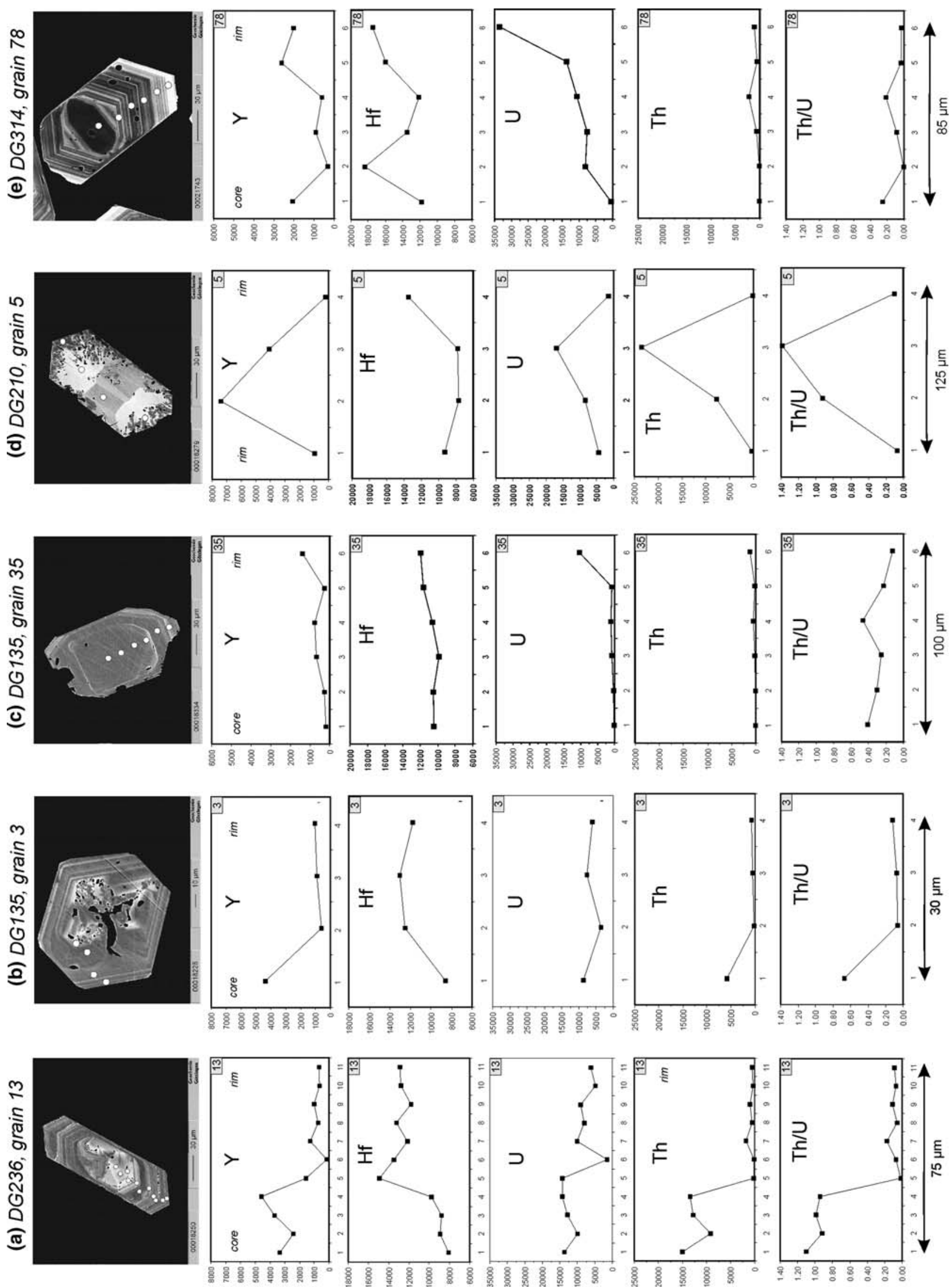
feature of the granite porphyry zircons. The range of $\mathrm{Th} / \mathrm{U}$ in the granite porphyry zircons (between 0.1 and 0.4 ; Fig. $6 \mathrm{a}, \mathrm{b})$ is considerably less than those in the monzogranite and related products $(\mathrm{Th} / \mathrm{U}=0-1.4)$. The zoning patterns in zircons from the Capraia dacite are relatively monotonous compared to zircons in Elba and lack large chemical variations (Fig. 6c, d).

Compared to other elements, the relative simplicity of the Hf zoning patterns, especially in the Monte Capanne and granite porphyry zircons, is noteworthy. Apart from
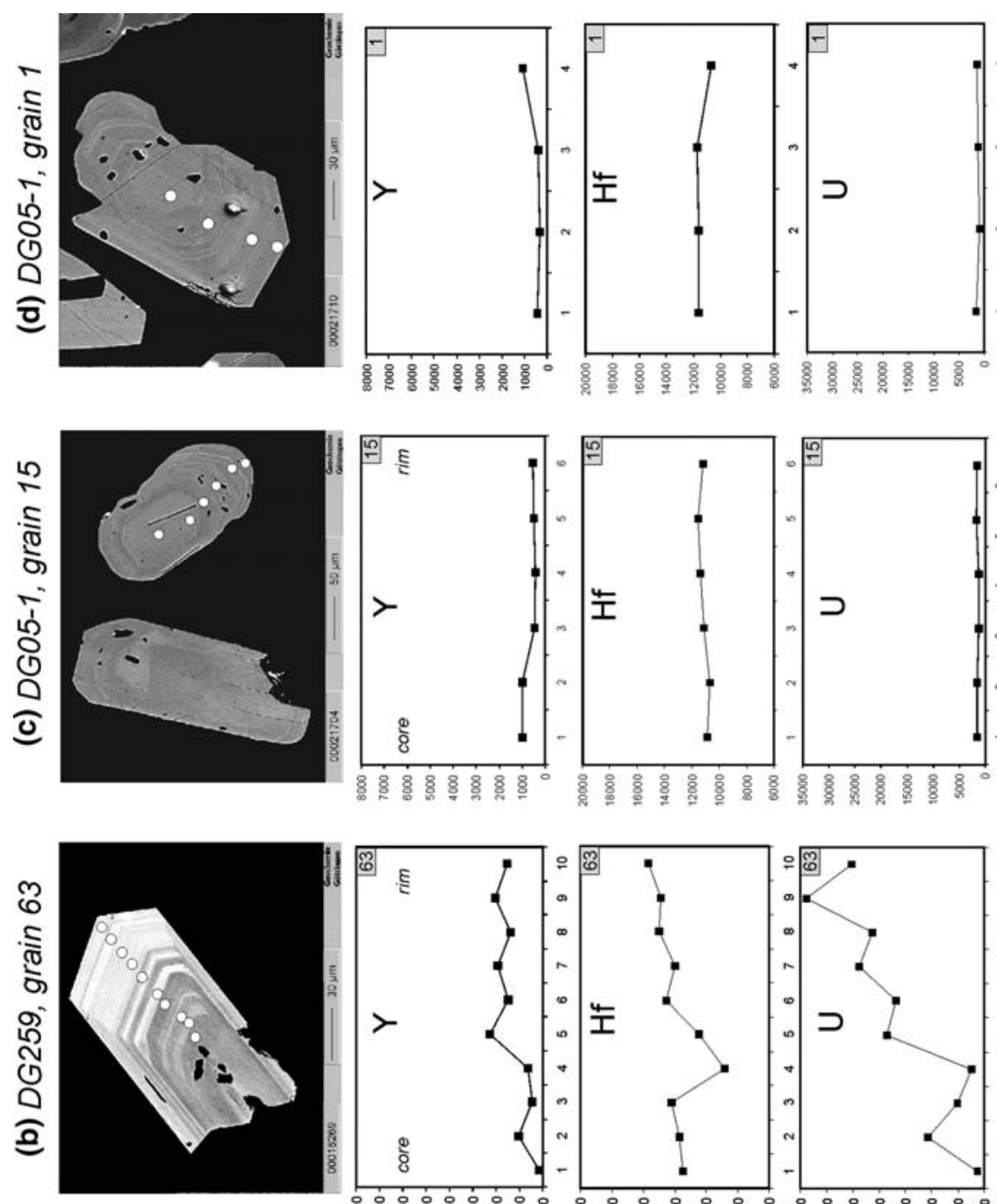

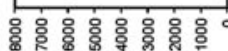
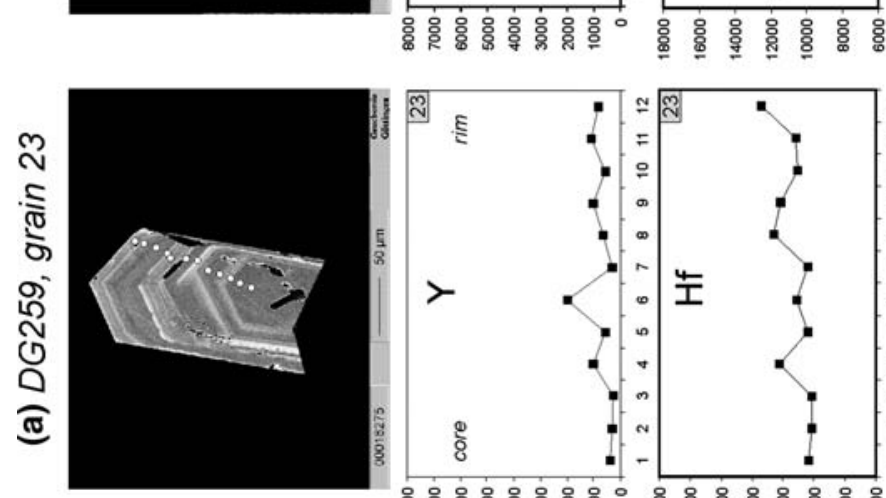

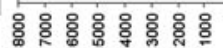
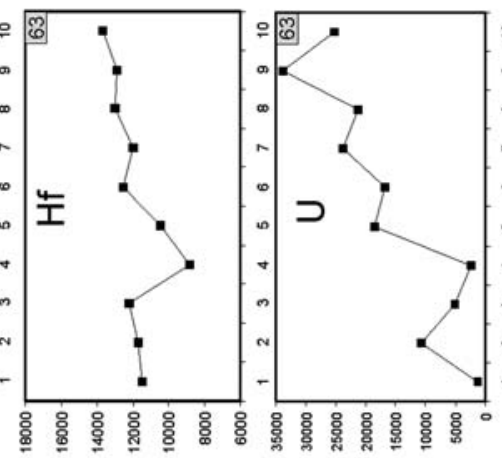
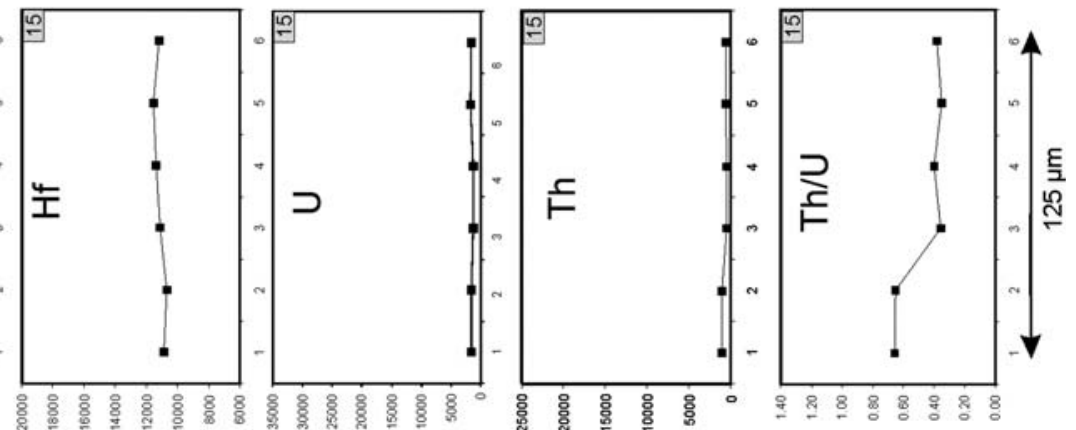
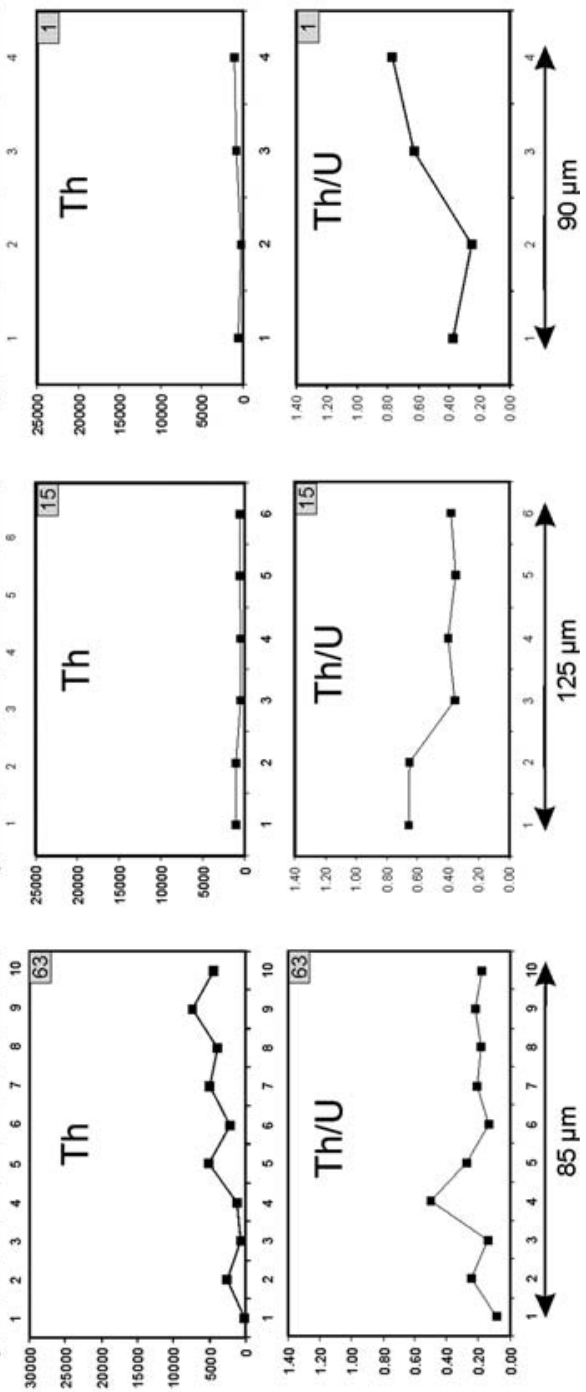

Fig. 6 Selected $\mathrm{Y}, \mathrm{Th}, \mathrm{U}, \mathrm{Hf}$ and $\mathrm{Th} / \mathrm{U}$ compositional profiles in zircons from the granite porphyry sample (DG259) and the Capraia dacite (DG05-1). Electron microprobe spots, corresponding to the

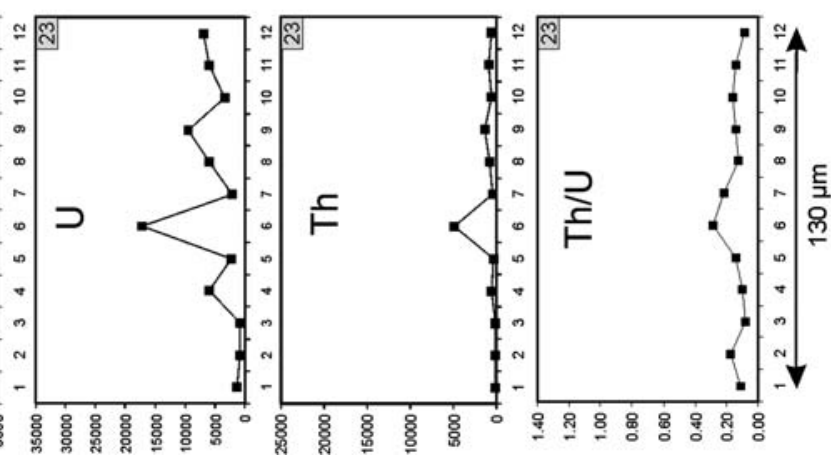

compositional profiles, are shown as white filled circles. Errors are smaller than symbol size 
excursions (not linked to episodes of resorption), a general rimward increase of the Hf concentration is noteworthy, which may be independent of the behaviour of other elements (Figs. 5, 6).

\section{Discussion}

Origin of the patchy-zoning texture:

a dissolution-recrystallization process?

Patchy-zoning texture characterizes most zircon cores in the monzogranite, MME and the Orano dyke. It is a disequilibrium texture, manifest by the replacement of U-ThY-rich zircon by U-Th-Y-poor zircon, as well as abundant pores, and Th-U-rich micro-inclusions in some cases. Such disequilibrium textures have been described in zircons from metamorphic rocks (Tomaschek et al. 2003; Spandler et al. 2004) as well as in pegmatites and granite (Xie et al. 2005), and have been reproduced experimentally (Geisler et al. 2003; Tomaschek 2004). In all these cases, the texture has been attributed to fluid interaction with zircon.

In a magmatic setting, low temperature, hydrothermal processes could have produced the porous cores (Fig. 5). However, two lines of evidence suggest otherwise. First, hydrothermal processes would be expected to operate at a late magmatic stage, but the texture is only found in the core, i.e. at an early stage of magma differentiation. Second, porous zircon is systematically overgrown by oscillatory idiomorphic zoning, which is typically magmatic in origin (Hoskin and Schaltegger 1993, and references therein).

Cavity-rich cores could also be derived from inherited zircons (Wang et al. 2002). However, ion microprobe $\mathrm{U}-\mathrm{Pb}$ data for the MC pluton (Daly et al. 2007; Gagnevin et al. $2008 \mathrm{~b}$ ) indicate that old grains (age $>150 \mathrm{Ma}$ ) have a rather homogenous, non-porous, texture, with rather low minor element abundances $(\mathrm{U}<1,500 \mathrm{ppm} ; \mathrm{Y}<600 \mathrm{ppm}$ ), which is consistent with other studies (Kopper and Sommerauer 1974). Demonstrably inherited zircons correspond to the unzoned to weakly zoned grains described above (Fig. 2h), which, from their lack of magmatic overgrowths are interpreted to be wall-rock xenocrysts. From its anhedral habit and low to minor trace element abundances, the core of grain 12 in sample DG220 (Fig. 2g) displays all the textural and chemical characteristics of an inherited core, and has a ${ }^{207} \mathrm{~Pb} /{ }^{206} \mathrm{~Pb}$ age of $2,509 \pm 14 \mathrm{Ma}$ (Daly and Gagnevin, unpublished data). Correlatively, low U-Th-Y zircon in patchy-zoned cores could also represent original inherited cores. However, this disagrees with the fact that (1) patchyzoned cores have 'magmatic' ages (from 7 to $8 \mathrm{Ma}$; Daly et al. 2007) and (2) low U-Th-Y zircon is a replacement product of original high $\mathrm{U}-\mathrm{Th}-\mathrm{Y}$ zircon, inferred to be the result of crystallization in silicic melts.
Crystal-plastic deformation could provide an alternative origin for the patchy zoning in the MC zircons, since it can produce intra-grain micro-structures and variations in crystallographic orientation (Timms et al. 2006; Reddy et al. 2009; Timms and Reddy 2009), generating discrete crystal boundaries and enhancing diffusion of some trace elements (Th, U, REE; Timms et al. 2006; Reddy et al. 2009). We consider this possibility rather unlikely. First, crystal-plastic deformation cannot explain the association of pores (sometimes associated with micro-inclusions) with the patchy-zoning texture (Fig. 2a-c). Second, only twofold enrichments of Th and $U$ have been reported as due to crystal plasticity (Timms et al. 2006), which contrasts sharply with the extreme compositional variations observed in this study (especially for Th; Fig. 5). Third, crystal-plastic deformation would tend to produce a polygonal network and the effect would preferentially affect that crystal edges (Reddy et al. 2009). In contrast, as shown particularly by the CL images (Electronic Appendix 1b), the textures in the MC zircon patchy-zoned cores are highly irregular and not restricted to the outer cores.

Thus, the patchy-zoning texture is ascribed to some disequilibrium process during zircon growth in a rather hightemperature environment $\left(>700^{\circ} \mathrm{C}\right)$. The detailed study of Geisler et al. (2007) inferred a diffusion-limited dissolutionrecrystallization process along a reaction front as a cause for disequilibrium during zircon growth, which strikingly resembles the patchy-zoning texture observed in the MC zircons. This process is dynamic and occurs along inwardmoving interfaces (e.g. Putnis 2002). Micrometer-sized pores, which may be a criterion for such a reaction (Tomaschek et al. 2003), result from differences in the molar volume between the parent zircon and the reprecipitated zircon. Such pores enhance exchange of elements during dissolution by creating a pathway from the reaction front (Geisler et al. 2007). In the MC zircons, pores tend to occur in the reacted high $\mathrm{U}-\mathrm{Th}-\mathrm{Y}$ zircon phase in close proximity to the contact between low and high $\mathrm{U}-\mathrm{Th}-\mathrm{Y}$ zircons (Figs. 2a, e, 3), which may represent the reaction front. Irregular, variably sized, inward-penetrating pores in grain interiors (e.g. Figs. 2c, 3a) may represent channels along which dissolution and recrystallization took place. It is inferred that dissolution and recrystallization occurred simultaneously (Geisler et al., 2007), as suggested by evidence of inward replacement (Fig. 2a, e) along porous zircon.

Magma mixing and relationships with other accessory phases

High concentrations of minor to trace elements (especially $\mathrm{U}$ and $\mathrm{Th}$ ) are generally accepted as evidence of zircon growth in silicic $(>70 \mathrm{wt} \%)$ magmas (e.g. Miller and Wooden 2004; Lowery Claiborne et al. 2006), while low 
HREE and $\mathrm{Y}$ in zircon are a signature of growth in mafic, mantle-derived magmas (Belousova et al. 1998; Hoskin and Ireland 2000). We conducted mixing calculations (Langmuir et al. 1978) in order to test if the patchy-zoned zircon cores would follow simple mixing trends (Fig. 7). Mixing curves involving $\mathrm{Y}$ and $\mathrm{U}$ generally fit the data, including the oscillatory-zoning texture (Fig. 7a). In contrast, $\mathrm{Y}$ versus Th exhibits a linear to convex-upwards pattern, in contrast to the concave-up trends (Fig. 7b) to be expected in the case of magma mixing. This suggests that factors other than melt composition must have operated in order to heavily fractionate Th relative to other elements.

In peraluminous granitoids, monazite is an abundant accessory phase (Förster 1998), and, together with Thorthosilicates, is a Th 'scavenger' (Montel 1993). It is thought that both zircon and monazite, which are found throughout the MC pluton, were in equilibrium with the peraluminous silicic melt at an early stage of magmatic differentiation. However, monazite varies widely in Th content $\left(\mathrm{ThO}_{2}=10-43 \mathrm{wt} \%\right.$; Dini et al. 2004) to a much greater extent than zircon $\left(\mathrm{ThO}_{2}=0-5.2 \mathrm{wt} \%\right)$, due to its participation in various reactions. Dini et al. (2004) highlighted complex reaction micro-textures involving Th-rich (huttonitic) monazite, monazite, allanite and apatite in the Pomonte facies of the MC monzogranite. These reactions, which were interpreted as the result of magma mixing between peraluminous [with aluminium saturation index $($ ASI $)>1$ ) and metaluminous (ASI $<1$ ) melts, are indicative of complex elemental transfer between melts and accessory minerals (Dini et al. 2004):

Reaction 1 (widespread): monazite

+ Ca-rich mafic melt $\rightarrow$ apatite + allanite

Reaction 2 (rare): apatite + silicic Al-Si melt

$\rightarrow$ Huttonic monazite + Ca-Al melt

Following reactions (1) and (2), we suggest that differential partitioning of Th relative to other elements that may be related to the co-crystallization of two generations of monazite during/after magma mixing (Dini et al. 2004), that is, monazite being replaced by apatite and allanite (another Th scavenger), and formation of huttonitic monazite by incongruent dissolution of fluorapatite. This again presupposes that monazite was already present in the melt and was in equilibrium with zircon before interaction with the apatite-bearing metaluminous melts. Th fractionation would be enhanced by the co-crystallization of Th-rich inclusions (such as thorite) sometimes (Figs. 2, 6) preserved in patchy-zoned cores, which results from the inferred dissolution-recrystallization process. Whether or not co-crystallization of other accessory phases during mixing influenced partitioning of $\mathrm{U}$ and $\mathrm{Y}$ is less clear. The good fit on the U-Y mixing model (Fig. 7a) suggests
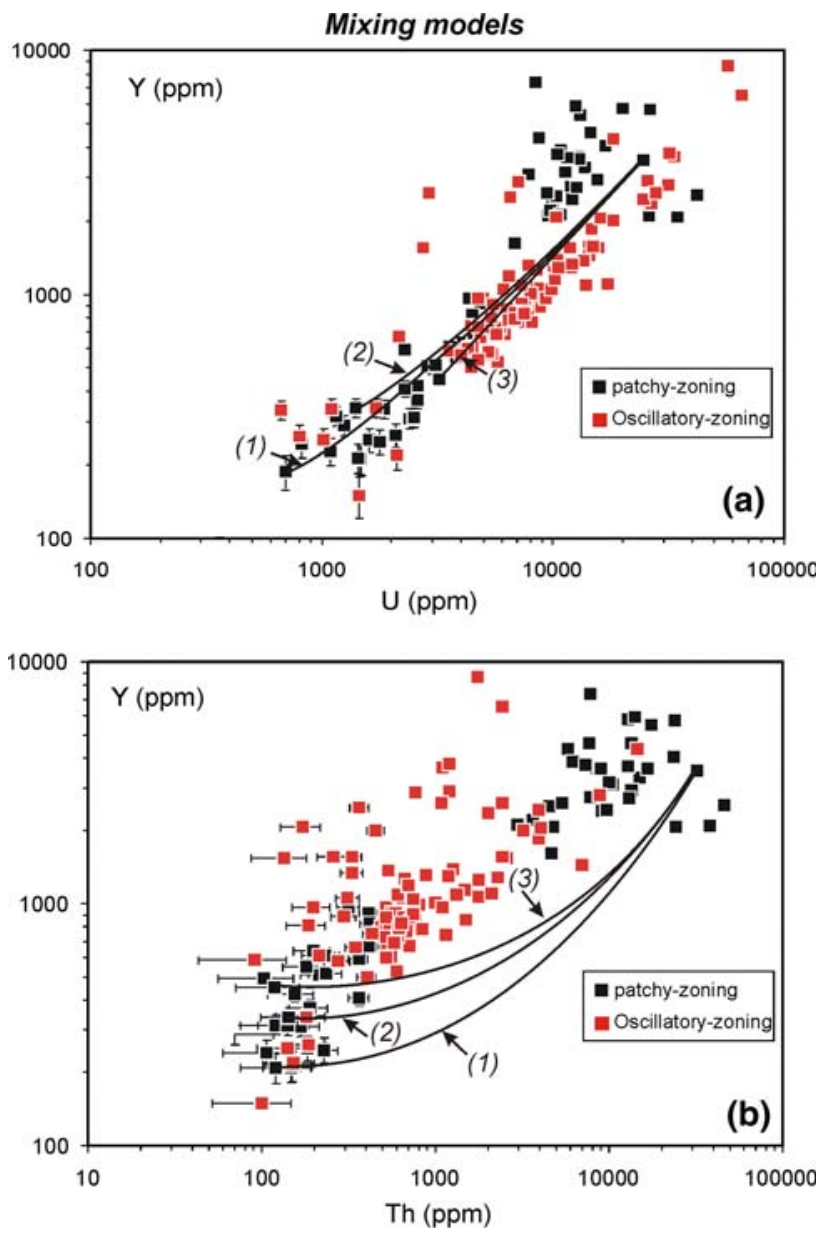

Fig. 7 Mixing models following Langmuir et al. (1978) using one UTh-Y-rich zircon to represent the felsic end-member and three U-ThY-poor zircons to represent mafic end-members. a Despite some scatter at high values, note the $\mathrm{U}-\mathrm{Y}$ mixing models provide a good fit to the data from the oscillatory-zoned zircon domains. b Using the same U-Th-Y-rich end-member, the Th-Y mixing models fail to fit the data. This suggests co-crystallization of monazite throughout most of the crystallization history recorded by zircon

open-system behaviour and indicates that co-crystallization of other accessory phases may have been subordinate compared to the effect of changing the melt composition.

The mixing event that created the patchy-zoning texture cannot account for the scatter of the data at high U-Th-Y values (Fig. 7). Decoupling U and Th from Y (Fig. 7a, b) implies that other processes, such as some minor fractionation and competition for $\mathrm{Y}$ by another accessory mineral, or non-equilibrium partitioning of $\mathrm{Y}$ (and HREE) at high $\mathrm{U}$ and $\mathrm{Th}$ contents may have been responsible.

Similarly, the correlation between U and Hf (Fig. 3c) does not follow typical mixing trends. The incorporation of $\mathrm{Hf}$ in the zircon lattice seems to be strongly dependant on the temperature rather than the melt chemistry (Lowery Claiborne et al. 2006; Watson et al. 2006). This is further suggested by the strong anti-correlation between $\mathrm{Hf}$ and 


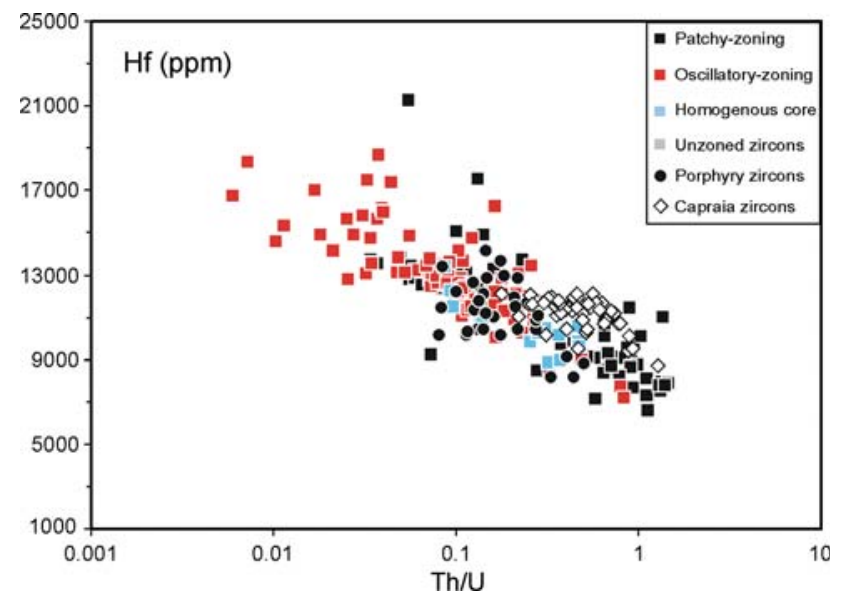

Fig. 8 Co-variation of $\mathrm{Hf}$ with $\mathrm{Th} / \mathrm{U}$ ratio in the different textural varieties of zircon. The good correlation between $\mathrm{Hf}$ and $\mathrm{Th} / \mathrm{U}$ ratio suggests that the $\mathrm{Th} / \mathrm{U}$ ration varies strongly with temperature, as opposed to the melt composition

$\mathrm{Th} / \mathrm{U}$ (Fig. 8), as this ratio has shown to be sensitive to temperature variations (Bolhar et al. 2008). Hence, the core-to-rim increase of $\mathrm{Hf}$ observed in most zircon grains (Fig. 5; Electronic Appendix 2) may thus mirror magma differentiation (Linnen and Keppler 2002; Hoskin and Schaltegger 1993) during crystal fractionation (Benisek and Finger 1993). In turn, sharp indentations towards lower Hf values (e.g. Fig. 5e) provide evidence of reheating of the magma chamber after recharge (rejuvenation).

Replenishment with hot, mafic metaluminous melts induced variable degrees of zircon resorption (i.e. patchyzoning texture), which may have occurred either in mafic enclaves or in the lower zones of the magma chamber (Gagnevin et al. 2005a). The zircons in the mafic enclave DG210 are particularly interesting in view of their unusual dissolution texture (e.g. Fig. 2e) as well their clear crustal signature (high $\mathrm{Y}$, Th and Th/U; Fig. 5d). These zircons originally crystallized from crustal melts and were later incorporated into the enclave during mixing, where they experienced variable resorption and replacement by $\mathrm{U}-\mathrm{Th}-$ Y-poor zircon. That they lack oscillatory zoning is consistent with their having remained within the enclave, i.e. they were not recycled back into the host magma. This contrasts with zircons in mafic enclave DG220, which have textural and chemical characteristics similar to zircons in the host monzogranite, suggesting a more complex thermal history and crystal transfer between host and enclave.

Andesitic-dacitic rocks from Capraia $(35 \mathrm{~km} \mathrm{NW}$ of Elba; Fig. 1) represent the most likely candidate for the mantle-derived melt end-member (Poli 1992; Dini et al. 2002; Gagnevin et al. 2004, 2005a, b). Chemically, the homogenous cores resemble zircons from the Capraia dacite (Fig. 4), but also have affinities with xenocrystic grains and inherited cores (Fig. 3). While the lack of magmatic overgrowth in wall-rock xenocrysts help to distinguish between xenocrysts and homogenous cores, the distinction between homogenous magmatic cores and inherited cores is not as straightforward. We have distinguished those on the basis of the overall shape of the core, as well as in situ SIMS U-Pb geochronology and $\mathrm{Hf}$ isotopic data (Gagnevin and Daly, unpublished data). Generally, homogenous magmatic cores have euhedral to subhedral outlines, and are of larger size $(>50 \mu \mathrm{m}$; Fig. $2 \mathrm{~d})$ than inherited cores (e.g. grain 12, DG220; Fig. 2g). Moreover, the Hf isotopic composition of the homogenous magmatic cores is typically similar to the patchy-zoned cores, while inherited cores and xenocrystic grains differ significantly, extending towards more crustal, less radiogenic, values (Gagnevin et al. 2008b). On these bases, we found that six homogenous cores are most likely magmatic and of Capraia affinity such as grain 35, DG135 (Figs. 2d, 6e) and grain 78, DG314 (Fig. 5e). A possible exception is grain 10, DG220 (Fig. 2f), which plots in a position intermediate between the low and high U-Th-Y patchy cores (Fig. 3), and is likely to represent the end product of the above-mentioned dissolution-recrystallization process.

The scarcity of inherited cores in the MC pluton (total of three) suggests that the granitic magma was initially zirconium-undersaturated (implying dissolution of sourcerelated zircons in presumably wet melts; Harrison and Watson 1983). Extensive dissolution of source-related 'inherited' zircons (which may have occurred in the hightemperature source region; Harley et al. 2007) may thus provide an explanation for the rather unusual high U-Th$\mathrm{Y}, \mathrm{Th} / \mathrm{U}$ and $\mathrm{Hf}$ compositions of the first generation of zircon crystallizing from the crustal magma.

Insights from oscillatory zoning

Oscillatory zoning, which mostly occurs in the rim regions of the zircons investigated here, is widely used to diagnose a magmatic origin. This texture can be viewed as a nonlinear phenomenon involving diffusive feedback between crystal growth and the surrounding environment (Hoskin 2000; Fowler et al. 2002). It is therefore not indicative of the melt composition as a whole, but, on the other hand, is a response to large-scale changes in the growth medium, such as influxes of magmas or fluids. The chemical scatter of the oscillatory-zoned domains is indicative of a complex origin. However, a large proportion of the data plots between the two patchy-zoned end-members for most elements (Fig. 3), which is interpreted as reflecting hybridisation following the initial mixing events, further corroborated by the good fit for the U-Y mixing model (Fig. 7a). U-Th-Y-rich layers may be sharply intercalated with U-Th-Y-poor layers (sometimes separated by resorption events; Fig. 2a, j), indicating that individual 
zircons were alternatively immersed in melts of contrasting composition. Each zircon crystal has a unique oscillatory zoning growth pattern, suggesting that mixing and further hybridization may have occurred dynamically in a chaotic fashion (Perugini et al. 2003).

The transition from high U-Th-Y zircon in patchyzoned cores to oscillatory zoning is characterised by a sharp drop in U, Th and Y. This steep chemical gradient suggests rapid zircon growth in response to magma influx (Benisek and Finger 1993). The drop is more accentuated for $\mathrm{Th}$, which decreases by more than $95 \%$ compared to other elements such as $U$ and Y, which decrease by 50 $80 \%$ (e.g. Fig. 5a). The outer oscillatory-zoned zircon exhibits little variation in Th. These two observations suggest that monazite was a stable phase and an efficient Th sink throughout the differentiation history recorded by zircon. Oscillatory zoning in the MC zircons is often terminated by U-rich, and to a lesser extent, Th-rich rims (Figs. 2b, f, 6d, e), which is indicative of extreme fractionation, perhaps in the presence of a vapour phase as suggested by enrichment of $U$ relative to $T h$ (Bacon et al. 2007) (Fig. 3a). Similarly, together with high $U$ and $Y$ contents, elevated $\mathrm{P}$ and $\mathrm{Ca}$ concentrations in some zircon rims (e.g. Table 2, sample DG236, grain 19, analysis \#42) suggest zircon crystallization in residual, peraluminous and hydrous melts (Breiter et al. 2006). The possibility that the high $U$ contents of the rims were the result of fortuitous sampling of micro-inclusions has been ruled out by replicate analysis (e.g. grain 19, DG236, Fig. 2b). We are thus confident that the high U-Th signature reflects zircon growth from a highly silicic, vapour-rich melt.

Oscillatory zoning is the predominant feature of zircons in the granite porphyry and the Capraia dacite (Fig. 6a, b). The large range of chemical composition in the granite porphyry zircons is comparable to zircons in the MC pluton (Fig. 4). The link between the stack of granite porphyries in Elba and the Monte Capanne pluton is unclear. The granite porphyries are older than the MC pluton, and different magma sources were envisaged to account for differences in their chemical and isotopic signatures (Dini et al. 2002). However, the similarity in zircon chemistry between the MC and porphyry indicates that both magmas may be related. It is indeed conceivable that granite porphyry-like peraluminous melts were added at some early stage of evolution in the MC magma chamber and was effectively recorded by the zircon chemical systematics. Being marginally older, it is also conceivable that a portion of the crystal zircon cargo was transferred and recycled into the MC magma(s). A possible example is grain 78, DG314 (Fig. 5e), which bears a strong similarity to grain 63, DG259 (Fig. 6b).

Zircons from Capraia display less chemical variation (Fig. 4) than those of the MC intrusion. As discussed above, homogenous cores may represent a fossil record of the zircon composition of the replenishing magma. In contrast to the homogenous cores, the Capraia zircons are armoured with fine-scale oscillatory-zoned rims with variable Th/U ratio (Fig. 6c, d), which represent an individual and separate record of the differentiation and magma mixing histories of the Capraia magma system (Gagnevin et al. 2007). In most cases, zircon core-to-rim variations are more subtle than in the MC zircons, consistent with growth in a less variable magmatic system closer to one endmember, of predominantly mantle affinity (Gagnevin et al. 2007).

\section{Conclusions}

This study provides important constraints on the petrogenesis of the Monte Capanne pluton, especially the evidence for magma mixing and the nature of the endmembers involved in this process. Observations on the texture and chemical composition of zircon provide unique insights into the various stages of magma differentiation. In particular, we provide an explanation for the genesis of the patchy-zoning texture in zircon, which is a widespread textural phenomenon in the Monte Capanne pluton, and is ascribed to disequilibrium during zircon growth at magmatic temperatures. This texture is the result of a diffusionlimited dissolution-recrystallization, which involves progressive replacement of high U-Th-Y zircon, thought to have crystallized from a crustal peraluminous melt in equilibrium with monazite, by low U-Th-Y zircon, interpreted to be a response of mixing between peraluminous and metaluminous melts. As far as the authors are aware, this study provides the first example of zircon re-equilibration in melts through a process of dissolution-recrystallization (Geisler et al. 2007).

Based on both chemical and textural observations on zircons from the MC pluton, we demonstrate that (1) the zircon Th budget was strongly influenced by concomitant dissolution and growth of other accessory minerals (cf. Dini et al. 2004), (2) hybridization occurred following the initial basic-silicic magma mixing event, and (3) extensive crystal-melt fractionation occurred towards the end of crystallization process in the MC pluton. Following previous studies (e.g. Dini et al. 2002; Gagnevin et al. 2004), the metaluminous end-member is inferred to belong to the Capraia volcanic system (North of Elba), a hypothesis that is supported by zircon data from one dacite sample from Capraia. Results show that despite different morphologies, the chemical signature of the Capraia dacite zircons resembles that of the homogenous, unresorbed cores in $\mathrm{MC}$ zircons. Thus, in addition to its traditional role as a geochronometer (e.g. Lowenstern et al. 2000; Bacon et al. 
2007), textural and chemical variations within individual zircon crystals can also offer an independent and robust link between co-genetic plutonic and volcanic systems that may, otherwise, remain cryptic.

Acknowledgments We thank Steve Reddy and Jochen Hoefs for reviews, both of which led to substantial improvements to the original manuscript. We also thank Giampiero Poli for his support during fieldwork in Elba and Capraia. This research was supported by Science Foundation Ireland (SFI) grant 04/BR/ES0007 awarded to J.S.D.

\section{References}

Bacon CR, Sisson TW, Mazdab FK (2007) Young cumulate complex beneath Veniaminof caldera, Aleutian arc, dated by zircon in erupted plutonic blocks. Geology 35(6):491-494

Belousova EA, Griffin WL, Pearson NJ (1998) Trace element composition and cathodoluminescence properties of southern African kimberlitic zircons. Mineral Mag 62(3):355-366

Belousova EA, Griffin WL, O’Reilly SY, Fisher NI (2002) Igneous zircon: trace element composition as an indicator of source rock type. Contrib Mineral Petrol 143(5):602-622

Belousova EA, Griffin WL, O'Reilly SY (2006) Zircon crystal morphology, trace element signatures and Hf isotope composition as a tool for petrogenetic modeling: examples from Eastern Australian granitoids. J Petrol 47(2):329-353

Benisek A, Finger F (1993) Factors controlling the development of prism faces in granite zircons-a microprobe study. Contrib Mineral Petrol 114(4):441-451

Bolhar R, Weaver SD, Palin JM, Cole JW, Paterson LA (2008) Systematics of zircon crystallisation in the Cretaceous Separation Point Suite, New Zealand, using U/Pb isotopes, REE and Ti geothermometry. Contrib Mineral Petrol 156(2):133-160

Breiter K, Förster HJ, Škoda R (2006) Extreme P-, Bi-, Nb-, Sc-, Uand F-rich zircon from fractionated perphosphorous granites: The peraluminous Podlesí granite system, Czech Republic. Lithos 88:15-34

Bussy F (1990) Petrogénèse des enclaves microgrenues associées aux granitoides calco-alcalins: exemples des massifs varisques du Mont-Blanc (Alpes occidentales) et Miocène du Monte Capanne (Ile d'Elbe, Italie). In: Mémoire de Géologie, No. 7., Lausanne, pp 309

Cavinato GP, De Celles PG (1999) Extensional basins in the tectonically bimodal central Appenines fold-thrust belt, Italy: response to corner flow above a subducting slab in retrograde motion. Geology 27(10):955-958

Cherniak DJ, Watson EB (2003) Diffusion in zircon. Rev Mineral Geochem 53:113-143

Conticelli S, Bortolotti V, Principi G, Laurenzi MA, D'Antonio M, Vaggelli G (2001) Petrology, mineralogy and geochemistry of a mafic dyke from Monte Castello, Elba Island, Italy. Ofioliti 26:249-262

Corfu F, Hanchar JM, Hoskin PWO, Kinny P (2003) Atlas of zircon textures. In: Hanchar JM, Hoskin PWO (eds) Zircon. Rev Mineral Geochem 53:469-500

Daly JS, Gagnevin D, Whitehouse MJ (2007) Zircon growth and resorption in an incrementally filled granite pluton: insights from in situ $\mathrm{U}-\mathrm{Pb}$, trace element and $\mathrm{Hf}$ isotopic analyses. Geochim Cosmochim Acta 71(15):A302

Dini A, Innocenti F, Rocchi S, Tonarini S, Westerman DS (2002) The magmatic evolution of the late Miocene laccolith-pluton-dyke granitic complex of Elba Island, Italy. Geol Mag 139:257-279
Dini A, Rocchi S, Westerman DS (2004) Reaction microtextures of REE-Y-Th-U accessory minerals in the Monte Capanne pluton (Elba Island, Italy): a possible indicator of hybridization processes. Lithos 78:101-118

Förster H-G (1998) The chemical composition of REE-Y-Th-U-rich accessory minerals in peraluminous granites of the ErzgebirgeFichtelgebirge region, Germany, Part I: the monazite-(Ce)brabantite solid solution series. Am Mineral 83:259-272

Fowler A, Prokoph A, Stern R, Dupuis C (2002) Organization of oscillatory zoning in zircon: analysis, scaling, geochemistry, and model of a zircon from Kipawa, Quebec, Canada. Geochim Cosmochim Acta 66(2):311-328

Gagnevin D, Daly JS, Poli G (2004) Petrographic, geochemical and isotopic constraints on magma dynamics and mixing in the Miocene Monte Capanne monzogranite (Elba Island, Italy). Lithos 78(1-2):157-195

Gagnevin D, Daly JS, Poli G, Morgan D (2005a) Microchemical and $\mathrm{Sr}$ isotopic investigation of zoned K-feldspar megacrysts: insights into the petrogenesis of a granitic system and disequilibrium crystal growth. J Petrol 46(8):1689-1724

Gagnevin D, Daly JS, Waight TE, Morgan D, Poli G (2005b) Pb isotopic zoning of $\mathrm{K}$-feldspar megacrysts determined by laser ablation multi-collector ICP-MS: insights into granite petrogenesis. Geochim Cosmochim Acta 69(7):1899-1915

Gagnevin D, Waight TE, Daly JS, Poli G, Conticelli S (2007) Insights into magmatic evolution and recharge history in Capraia Volcano (Italy) from chemical and isotopic zoning in plagioclase phenocrysts. J Volcanol Geotherm Res 168:28-54

Gagnevin D, Daly JS, Poli G (2008a) Insights into granite petrogenesis from quantitative assessment of the field distribution of enclaves, xenoliths and K-feldspar megacrysts in the Monte Capanne Pluton, Italy. Mineral Mag 72(4):925-940

Gagnevin D, Daly JS, Whitehouse MJ, Horstwood M, Kronz A (2008b) Zircon as proxy of magma differentiation and mixing in the Tuscan magmatic province (Italy). Goldschmidt Conference Abstracts, A288

Geisler T, Pidgeon RT, Kurtz R, van Bronswijk W, Schleicher H (2003) Experimental hydrothermal alteration of partially metamict zircon. Am Mineral 86:1496-1518

Geisler T, Schaltegger U, Tomaschek F (2007) Re-equilibration of zircon in aqueous fluids and melts. Elements 3(1):43-50

Hanchar JM, Miller CF (1993) Zircon zonation patterns as revealed by cathodoluminescence and backscattered electron imagesimplications for interpretation of complex crustal histories. Chem Geol 110(1-3):1-13

Hanchar JM, Finch RJ, Hoskin PWO, Watson EB, Cherniak DJ, Mariano AN (2001) Rare earth elements in synthetic zircon: Part 1. Synthesis, and rare earth element and phosphorus doping. Am Mineral 86:667-680

Harley SL, Kelly NM, Möller A (2007) Zircon behaviour and the thermal histories of Mountain Chains. Elements 3:25-30

Harrison TM, Watson EB (1983) Kinetics of zircon dissolution and zirconium diffusion in granitic melts of variable water content. Contrib Mineral Petrol 84:67-72

Hoskin PWO (2000) Patterns of chaos: fractal statistics and the oscillatory chemistry of zircon. Geochim Cosmochim Acta 64(11):1905-1923

Hoskin PWO (2005) Trace-element composition of hydrothermal zircon and the alteration of Hadean zircon from the Jack Hills, Australia. Geochim Cosmochim Acta 69(3):637-648

Hoskin PWO, Ireland TR (2000) Rare earth element chemistry of zircon and its use as a provenance indicator. Geology 28(7):627630

Hoskin PWO, Schaltegger U (1993) The composition of zircon and igneous and metamorphic petrogenesis. Rev Mineral Geochem $53: 27-62$ 
Hoskin PWO, Kinny PD, Wyborn D, Chappell BW (2000) Identifying accessory mineral saturation during differentiation in granitoid magmas: an integrated approach. J Petrol 41(9):1365-1396

Kemp AIS, Hawkesworth CJ, Foster GL, Paterson BA, Woodhead JD, Hergt JM, Gray CM, Whitehouse MJ (2007) Magmatic and crustal differentiation history of granitic rocks from $\mathrm{Hf}-\mathrm{O}$ isotopes in zircon. Science 315:980-983

Kopper V, Sommerauer J (1974) Trace-elements and behaviour of U$\mathrm{Pb}$ system in inherited and newly formed zircons. Contrib Mineral Petrol 43(1):71-82

Langmuir CH, Vocke RD Jr, Hanson GN (1978) A general mixing equation with applications to Icelandic basalts. Earth Planet Sci Lett 37:380-392

Linnen RL, Keppler H (2002) Melt composition control of $\mathrm{Zr} / \mathrm{Hf}$ fractionation in magmatic processes. Geochim Cosmochim Acta 66(18):3293-3301

Lowenstern JB, Persing HM, Wooden JL, Lanphere MA, DonnellyNolan JM, Grove TL (2000) U-Th dating of single zircons from young granitoid xenoliths: new tools for understanding volcanic processes. Earth Planet Sci Lett 183:291-302

Lowery Claiborne L, Miller CF, Walker BA, Wooden JL, Mazdab FK, Bea F (2006) Tracking magmatic processes through $\mathrm{Zr} / \mathrm{Hf}$ ratios in rocks and $\mathrm{Hf}$ and Ti zoning in zircons: an example from the Spirit Mountain batholith, Nevada. Mineral Mag 70:517-543

Miller JS, Wooden JL (2004) Residence, resorption and recycling of zircons in Devils Kitchen rhyolite, Coso Volcanic field, California. J Petrol 45(11):2155-2170

Miller JS, Matzel JEP, Miller CF, Burgess SD, Miller RB (2007) Zircon growth and recycling during the assembly of large, composite arc plutons. J Volcanol Geotherm Res 167:282-299

Montel JM (1993) A Model for monazite/melt equilibrium and application to the generation of granitic magmas. Chem Geol 110(1-3):127-146

Murakami T, Chakoumakos BC, Ewing RC, Lumpkin GR, Weber WJ (1991) Alpha-decay event damage in zircon. Am Mineral 76:1510-1532

Nasdala L, Kronz A, Hanchar JM, Tichomirowa M, Davi DW, Hofmeister W (2006) Effects of radiation damage on backscattered electron imaging of single crystals of minerals. Am Mineral 91:1739-1746

Perugini D, Busà T, Poli G, Nazzareni S (2003) The role of chaotic dynamics and flow fields in the development of disequilibrium textures in volcanic rocks. J Petrol 44(4):733-756

Pettke T, Audetat A, Schaltegger U, Heinrich CA (2005) Magmaticto-hydrothermal crystallization in the $\mathrm{W}-\mathrm{Sn}$ mineralized mole granite (NSW, Australia)—Part II: evolving zircon and thorite trace element chemistry. Chem Geol 220(3-4):191-213

Poli G (1992) Geochemistry of Tuscan Archipelago granitoids, Central Italy: the role of hybridization processes in their genesis. J Geol 100:41-56

Poli G, Perugini D (2003) The island of Capraia. In: Poli G, Perugini D, Rocchi S, Dini A (eds) Miocene to recent plutonism and volcanism in the Tuscan Magmatic Province (Central Italy), Periodico di Mineralogia LXXII(2):195-200

Poller U, Huth J, Hoppe P, Williams IS (2001) REE, U, Th, and Hf distribution in zircon from Western Carpathian Variscan granitoids: a combined cathodoluminescence and ion microprobe study. Am J Sci 301(10):858-876

Putnis A (2002) Mineral replacement reactions: from macroscopic observations to microscopic mechanisms. Mineral Mag 66(5):689-708
Reddy SM, Timms NE, Hamilton PJ, Smyth HR (2009) Deformationrelated microstructures in magmatic zircon and implications for diffusion. Contrib Mineral Petrol 157(2):231-244

Rocchi S, Westerman DS, Dini A, Innocenti F, Tonarini S (2002) Two-stage growth of laccoliths at Elba Island, Italy. Geology 30:983-986

Spandler C, Hermann J, Rubatto D (2004) Exsolution of thortveitite, yttrialite, and xenotime during low-temperature recrystallization of zircon from New Caledonia, and their significance for trace element incorporation in zircon. Am Mineral 89:1795-1806

Thomas JB, Bodnar RJ, Shimizu N, Sinha AK (2002) Determination of zircon/melt trace element partition coefficients from SIMS analysis of melt inclusions in zircon. Geochim Cosmochim Acta 66(16):2887-2901

Timms NE, Reddy SM (2009) Response of cathodoluminescence to crystal-plastic deformation in zircon. Chem Geol 261(1-2):1123

Timms NE, Kinny PD, Reddy SM (2006) Enhanced diffusion of uranium and thorium linked to crystal plasticity in zircon. Geochem Transact 7:10

Tomaschek F (2004) Zircon reequilibration by dissolution-reprecipitation: reaction textures from flux-grown solid solutions. Beihefte zum Eur J Mineral 12:214

Tomaschek F, Kennedy AK, Villa IM, Lagos M, Ballhaus C (2003) Zircons from Syros, Cyclades, Greece-recrystallization and mobilization of zircon during high-pressure metamorphism. J Petrol 44(11):1977-2002

Trevisan L, Marinelli G (1967) Carta geologica dell'Isola d'Elba (scala 1:25000). Consiglio Nazionale delle Ricerche

Wang X, Griffin WL, O'Reilly SY, Zhou XM, Xu XS, Jackson SE, Pearson NJ (2002) Morphology and geochemistry of zircons from late Mesozoic igneous complexes in coastal SE China: implications for petrogenesis. Mineral Mag 66(2):235-251

Wark DA, Miller CF (1993) Accessory mineral behavior during differentiation of a granite suite-monazite, xenotime and zircon in the Sweetwater Wash Pluton, Southeastern California, USA. Chem Geol 110(1-3):49-67

Watson EB, Harrison TM (1983) Zircon saturation revisited: temperature and composition effects in a variety of crustal magma types. Earth Planet Sci Lett 64:295-304

Watson EB, Wark DA, Thomas JB (2006) Crystallization thermometers for zircon and rutile. Contrib Mineral Petrol 151:413-433

Westerman DS, Dini A, Innocenti F, Rocchi S (2004) Rise and fall of a nested Christmas-tree laccolith complex, Elba Island, Italy. In: Breitkreuz, C, Petford, N (eds) Physical geology of high-level magmatic systems. Special Publication of the Geological Society of London 234:195-213

Wiedenbeck M, Hanchar JM, Peck WH, Sylvester P, Valley J, Whitehouse M, Kronz A, Morishita Y, Nasdala L (2004) Further characterization of the 91500 zircon crystal. Geostand Newsl 28:9-39

Xie L, Wang R, Chen X, Qiu J, Wang D (2005) Th-rich zircon from peralkaline A-type granite: mineralogical features and petrological implications. Chin Sci Bull 50:809-817

Yang JH, Wu FY, Wilde SA, Xie LW, Yang YH, Liu XM (2007) Tracing magma mixing in granite genesis: in situ $\mathrm{U}-\mathrm{Pb}$ dating and Hf-isotope analysis of zircons. Contrib Mineral Petrol 153(2):177-190 